\title{
Identifying and Charging True Perpetrators in Cases of Wrongful Convictions
}

\author{
Jennifer N. Weintraub \\ School of Criminal Justice, University at Albany, SUNY \\ U.S.A. \\ Kimberly M. Bernstein \\ School of Criminal Justice, University at Albany, SUNY \\ U.S.A.
}

True perpetrators - those who commit crimes that others were wrongfully convicted of-are a danger to society. Left unapprehended, these individuals often continue to commit crimes that could have otherwise been avoided. Despite the risk they pose, only about half of true perpetrators in DNA exoneration cases have been identified. Further, only 50\% of those who have been identified have been charged with the wrongful conviction crime(s) they committed. Previous research on wrongful convictions, prosecutorial discretion in charging decisions, and prosecutors' treatment of post-conviction innocence claims provide a starting point for investigating what factors underlie the identification and charging of true perpetrators. To explore these factors, we analyze 367 DNA exoneration cases and the consequent 149 unique, identified true perpetrators. Results revealed that prosecutorial misconduct as a contributor to the wrongful conviction decreased the odds that a true perpetrator would be identified, but the odds increased if the victim was White and the exoneree was Black compared to if both were White. Odds of identification also decreased when, compared to murder, the most severe wrongful conviction crime type was child sex abuse or sexual assault. These factors were not significantly associated with the odds of an identified true perpetrator being charged with a wrongful conviction crime. A qualitative study revealed both definitively prohibitive and potentially influential factors that could influence a prosecutor's decision not to charge an identified true perpetrator with these crimes. These findings indicate policy solutions that could hold true perpetrators of wrongful convictions crimes responsible for their actions.

I. Identifying and Charging True Perpetrators in Cases of Wrongful Convictions

II. Background

III. Current Studies

IV. Study One: Identifying True Perpetrators
A. Data and Methods
B. Results
C. Discussion

V. Study Two: Charging True Perpetrators
A. Data and Methods
B. Results
C. Discussion

VI. Study Three: Exploring Cases of Uncharged True Perpetrators

A. Data and Methods 

B. Results
C. Discussion
VII. General Discussion
References
Appendix

\section{Identifying and Charging True Perpetrators in Cases of Wrongful Convictions}

Wrongful convictions inflict upon an innocent person one of the world's greatest injustices - being convicted for a crime they did not commit. Broadly, there are two categories of wrongful convictions in which the wrongfully convicted individual is factually innocent: "nocrime" wrongful convictions where one is convicted for a crime that never occurred, and "wrongperson" wrongful convictions where the wrong person was convicted for the crime (Acker \& Redlich, 2011; Bingham et al., 2013). ${ }^{1}$ To date, there have been 367 DNA exonerations in the United States as defined by the Innocence Project; that is, 367 individuals determined by DNA evidence to be factually innocent of the crime for which they were convicted (Innocence Project, 2020). Furthermore, The National Registry of Exonerations (NRE) has estimated an additional $2,247^{2}$ exonerations have occurred across the United States since 1989 (The National Registry of Exonerations, n.d.-a). For each wrong-person wrongful conviction, there is at least one individual, the "true perpetrator," who actually committed the crime for which the exoneree was wrongfully convicted. As wrong-person wrongful convictions make up approximately $60 \%$ of all known wrongful convictions cases (Norris, Bonventre, \& Acker, 2018), true perpetrators have escaped culpability, at least initially, for a crime they actually committed in nearly 1,500 cases.

Although the literature regarding wrongful convictions broadly is extensive-covering a variety of factors including mistaken witness identification (e.g., Clark, 2012; Garrett, 2011), false or misleading forensic evidence (e.g., Cooper \& Meterko, 2019; Garrett \& Neufeld, 2009; Kassin, Dror, \& Kukucka, 2013), and the aftermath of wrongful convictions (e.g., Norris, 2014; Thompson, Molina, \& Levett, 2012; Westervelt \& Cook, 2012)_research about true perpetrators specifically is just beginning to develop. Most research on the topic aims to estimate the number of additional crimes true perpetrators commit due to instances of wrongful conviction (Baumgartner et al., 2018; Conroy \& Warden, 2011; Norris, Weintraub, et al., 2019; West \& Meterko, 2016). The consensus across this line of work is that when true perpetrators escape justice, they continue to pose a significant public safety risk by committing additional serious crimes. Only recently has research started to examine factors that influence whether or not true perpetrators are identified (Weintraub, 2020), but scholars have speculated that contributors to wrongful convictions, such as false confessions, may affect the likelihood of true perpetrator identification (Norris, Weintraub, et al., 2019). Additional work is needed to understand the factors underlying the identification of true perpetrators so that more of these individuals can be identified and a more accurate estimate of the harm they cause produced.

\footnotetext{
${ }^{1}$ There also exists a third type of wrongful conviction, which occurs when someone is factually guilty of a crime and convicted, but there are procedural errors with their case (Gould \& Leo, 2010; Medwed, 2008). However, studies which discuss wrongful convictions almost exclusively focus on factually innocent wrongful convictions, as do the present studies.

${ }^{2}$ Most recent data are as of 2 February 2020.
} 
However, just identifying true perpetrators is not enough to ensure public safety and justice; these outcomes hinge on these individuals then being charged with the crimes they committed for which someone else was wrongfully convicted. According to data provided by the Innocence Project, only half of identified true perpetrators in DNA exoneration cases have been charged with the wrongful conviction crime. It remains unknown why a full $50 \%$ of these individuals have not been charged with the wrongful conviction crime as this contradicts both the due process and crime control models of the criminal justice system (Acker, 2013; Packer, 1968). Thus, the present studies serve as an exploratory examination of what legal and extralegal factors might influence the identification and charging of a true perpetrator.

In the following sections, we discuss the importance of identifying and charging the true perpetrators of wrongful convictions offenses, hypothesize as to what factors will impact these outcomes, and empirically test the relation between the hypothesized factors and the identification (Study One) and charging (Study Two) of true perpetrators. Following these analyses, we explore individual wrongful convictions cases to identify additional definitively prohibitive and potentially influential factors related to prosecutorial discretion in charging a true perpetrator (Study Three). Finally, we discuss the policy implications of our findings and provide directions for future research.

\section{Background}

Since 2011, scholars have paid increasing attention to the damage true perpetrators inflict upon society, their victims, and not the least of which, the wrongfully convicted individuals. Broadly, members of the public find the possibility that the criminal justice system can punish an innocent person for another individual's crime to be concerning (Zalman, Larson, \& Smith, 2012). Additionally, cognizance of wrongful convictions can damage the public's trust in the criminal justice system (Gould \& Leo, 2010), and may even lead to decreased support for the death penalty (Baumgartner, DeBoef, \& Boydstun, 2008; Fan, Keltner, \& Wyatt, 2002; Norris \& Mullinix, 2019; Unnever \& Cullen, 2005). As explained by Jason Carmichael \& Stephanie Kent (2015), “The public's confidence in the criminal justice system is shaken as they grapple with both the public safety concern that the actual perpetrator is among them, as well as the disappointment in the system's concern with individual justice" (p.705). Recently, the issue has grown more salient to the public, as wrongful convictions are increasingly featured on the news, on streaming platforms, and in podcasts (Demos \& Ricciardi, 2015; Leveritt, 2002; Stratton, 2019; Zalman, Larson, \& Smith, 2012).

\section{Identifying True Perpetrators}

The concerns held by the public about the dangers of wrongful convictions are warranted, as the vast majority of true perpetrators commit at least one crime after someone else has been wrongfully convicted for their own criminal actions (Norris, Weintraub, et al., 2019). The identification of true perpetrators is necessary to know the full negative impact of their wrongful liberty on public safety. Studies quantifying true perpetrators' crimes have been done with samples ranging from state-wide wrongful convictions (Baumgartner et al., 2018; Conroy \& Warden, 2011), to national samples (Norris, Weintraub, et al., 2019; West \& Meterko, 2016). Extrapolated 
information about the criminal impact of true perpetrators in DNA exoneration cases to federal data on annual convictions has found that incarcerating the wrong individuals may lead to more than 41,000 additional crimes being committed each year (Norris, Weintraub, et al., 2019). Furthermore, the types of crimes that true perpetrators commit are not inconsequential. They are often serious crimes, categorized as violent or felony-level offenses (Baumgartner et al., 2018; Conroy \& Warden, 2011; West \& Meterko, 2016), and primarily consist of sexual assault as well as other violent crimes including armed robbery, aggravated assault, and homicide (Norris, Weintraub, et al., 2019; West \& Meterko, 2016). In these cases, identifying a true perpetrator can quite literally mean the difference between life and death. One analysis found that 39 serial homicide offenders altogether committed an additional 79 homicides after the wrong individuals were convicted for their first homicide crimes (Yaksic et al., 2020). Each of these studies notes, importantly, that an accurate estimate of true perpetrators' criminality is evasive. The only way for speculations to approach the true answer is to identify more true perpetrators.

Identifying true perpetrators is not only important for community safety and trust in the criminal justice system, but also to achieving justice for those who are wrongfully convicted. In a study of wrongful convictions and "near misses" 3 , true perpetrator identification was the basis for an exoneration in $58 \%$ of wrongful convictions and $57 \%$ of near misses. In fact, true perpetrator identification is second only to DNA evidence as a basis for exoneration (Gould \& Leo, 2015). Moreover, true perpetrator identification and DNA evidence often go hand-in-hand; DNA analysis, which is usually done in an attempt to obtain evidence of the wrongfully convicted person's innocence, can also identify a true perpetrator in the process. In cases where DNA analysis exonerates a wrongfully convicted individual, it can identify the true perpetrator either by direct match or comparison of a DNA sample from the crime scene to a suspect (Innocence Project, 2020).

Thomas Haynesworth is one example of an exoneree who had his case overturned because DNA evidence identified the true perpetrator. Haynesworth was accused and convicted of having committed multiple sexual assaults, while the true perpetrator remained free and committed more of these crimes. Twenty-five years after Haynesworth was wrongfully convicted, DNA evidence simultaneously cleared his name and matched Leon Davis, who had been apprehended by the state for the sexual assaults he had committed while Haynesworth was incarcerated. Had Davis been identified sooner, or been apprehended instead of Haynesworth, at least a dozen additional victims could have been spared from his crimes (Acker, 2013; Green \& Williams, 2009).

Identifying these actual perpetrators is the first step to ensuring justice is served, but the limited extant research on the topic leaves little direction for how best to empirically examine the factors underlying their identification. In an effort to do so, we first turn to factors most often associated with cases of wrongful convictions, hypothesizing that these factors are likely to also impact true perpetrator identification due to the close relation of the subjects. Specifically, we include defining characteristics of wrongful convictions cases, such as contributors to wrongful convictions (e.g., eyewitness misidentification and prosecutorial misconduct), case demographics (e.g., the most severe crime type and high volume exoneration county), and the assistance of an innocence organization (e.g., Gould, Carrano, Leo, \& Young, 2013; West \& Meterko, 2016). We

\footnotetext{
3 "Near misses" were defined by the authors as "those who had charges dismissed before conviction or were acquitted on the basis of factual innocence" (Gould \& Leo, 2015, p.333).
} 
then include additional factors that are related to criminal justice outcomes more broadly, such as race (e.g., Eberhardt et al., 2006; Viglione, Hannon, \& DeFina, 2011) and the advent of DNA technology (e.g., Bowman \& Gould, 2020; Weintraub, 2020). We hypothesize that, given the overarching effect of these variables in the criminal justice system, they likely impact outcomes for true perpetrator identification as well.

\section{Charging True Perpetrators}

Beyond just identifying who they are, charging true perpetrators with the wrongful conviction crime also contributes to maintaining public safety, and is likely important to exonerees' reentry to society after being wrongfully accused and held responsible for crimes they did not commit. When an innocent individual is charged and convicted, they lose not only their livelihood but their reputation due to beliefs by others that they committed a heinous crime. These beliefs often remain intact even if the exoneree's convictions are overturned or expunged from their record, as many continue to face prejudice in their daily lives and experience traumatic psychological effects from their wrongful conviction (Clow, Blandisi, Ricciardelli, \& Schuller, 2011; Westervelt \& Cook, 2008). Moreover, most exonerees never receive apologies or even acknowledgments of fault from those who had a hand in their wrongful conviction, although receiving one could be beneficial to their psychological well-being and reintegration (Penzell, 2007). Larry Fuller, an exoneree who did receive an apology from an Assistant District Attorney ("DNA Clears Man in Rape, Judge Rules," 2006), told the Innocence Project in an interview that an apology provides an "acknowledgment that they cannot deny you" and that with the apology, "the stigma [was] gone" (Penzell, 2007, pp. 145-146). Thus, charging the true perpetrators for their crimes could allow exonerees to face less public ridicule and gain some satisfaction that the state acknowledged and attempted to right its wrong.

Given these potential benefits, it is unclear why half of identified true perpetrators are not charged for the crimes they committed and for which someone else was held responsible. The decision to charge a true perpetrator may differ from a prosecutor's decision to charge other offenders, given the additional circumstances a prosecutor must consider when undertaking an exoneration case. These circumstances can include: the passage of a significant amount of time since the crime was committed and investigation was conducted (Gould \& Leo, 2015; Meterko, 2016); retraumatizing victim(s) who believe the case to have been resolved, and may have to cooperate with an entirely new investigation (Brody \& Acker, 2015; Irazola et al., 2013); an exonerated party that the prosecutor may not believe to be factually innocent (Westervelt \& Cook, 2008), and more. Still, the fundamental question for prosecutors remains the same: whether or not to bring charges against an offender. Therefore, we first explore research regarding prosecutorial discretion in non-exoneration cases, examining how this decision-making process may change for cases of true perpetrators.

Prosecutors have complete discretion in deciding whether or not to charge anyone accused of a crime (Albonetti, 1987; Jacoby, 1980). The decision is complex and based on several factors (Bowers, 2010; Gershman, 2010), requiring prosecutors to weigh a number of rationales when considering not charging an accused individual (Goldstein, 1981; Greenawalt, 1987; Miller, 1969). Altogether, these considerations can be condensed into three distinct groups, as laid out by Josh Bowers (2010): legal, equitable, and administrative. 
Legal considerations encompass whether a prosecutor has enough evidence to press charges against an accused person (Bowers, 2010; Goldstein, 1981; Miller, 1969; Wayte v. United States, 1985). However, these considerations are likely slightly different when deciding whether or not to charge a true perpetrator. Although a prosecutor may decline to charge a true perpetrator if they deem the available evidence insufficient to point to legal guilt, or if they believe the evidence does not adequately exonerate the wrongfully convicted individual and point to the true perpetrator, it is unlikely that there is an actual lack of available evidence. The fact-finding process to overturn a wrongful conviction is long and arduous, with research indicating that the exoneration process can be as long as 21.5 years, on average, from conviction to release (Meterko, 2016).

The time it takes to complete this lengthy process is partially due to the fact that the requirements to reverse a conviction can be quite burdensome. ${ }^{4}$ Although they are often held to be synonymous, one's factual innocence does not necessarily lead to an exoneration (Leo, 2017). Instead, significant evidence and proof must be gathered and submitted to the court via a specific process to secure a wrongfully convicted individual's release. For example, to vacate a judgment based on new evidence in New York, the Criminal Procedure Law requires that:

New evidence has been discovered since the entry of a judgment based upon a verdict of guilty after trial, which could not have been produced by the defendant at the trial even with due diligence on his part and which is of such character as to create a probability that had such evidence been received at the trial the verdict would have been more favorable to the defendant; provided that a motion based upon such ground must be made with due diligence after the discovery of such alleged new evidence (N.Y. CPL $\S 440.10$ ).

With such high standards required to exonerate an individual, there should be no dearth of evidence to at least begin compiling a case against the true perpetrator. Thus, it is likely factors other than legal considerations that account for why so many identified true perpetrators are not charged for their crimes.

The second group of considerations described by Josh Bowers (2010) are equitable factors. Prosecutors may weigh whether it is the just decision to charge a perpetrator depending on how they judge the character of the offender, the severity of the offense, or if doing so serves the best interests of the public (Goldstein, 1981; Greenawalt, 1987; Miller, 1969). In exoneration cases, a prosecutor choosing not to charge the true perpetrator may be a manifestation of their judgments that a prosecution is not necessary for any number of reasons, such as if the perpetrator is already incarcerated for another crime, or if they believe that the exoneree is still factually guilty despite being exonerated.

Lastly, practical or administrative considerations, such as whether there are enough resources to prosecute the case, can cause a prosecutor to decide against pressing charges (Bowers, 2010; Goldstein, 1981). Though adequate resources are necessary for any prosecution, those involving true perpetrators may actually require fewer resources than other cases because of the evidential burden required to exonerate the wrongfully convicted, as described above. Still,

\footnotetext{
${ }^{4}$ For a review of other factors that contribute to an exoneree's time to exoneration see Jon Gould \& Richard Leo (2015, pp.356-360).
} 
prosecutors may find it difficult to justify using resources to prosecute a true perpetrator for crimes someone else has already been previously convicted of. Overall, even though the decision to prosecute a true perpetrator is still within a prosecutor's discretion, the qualitative difference between cases borne out of wrongful convictions and those that are not makes it unlikely that these legal, equitable, and administrative considerations completely account for outcomes regarding the decision to charge true perpetrators. In addition, the decision is likely to be also related to the previously discussed criminal justice and wrongful conviction case factors, as well as how prosecutors process post-conviction innocence claims more broadly.

Prior research indicates that prosecutors are largely uncooperative with post-conviction innocence claims by simply failing to help overturn wrongful convictions or going so far as to stand in the way of exoneration efforts (Gould \& Leo, 2015; Webster, 2019). This unwillingness to cooperate may be especially likely to occur if the prosecutor still believes the wrongfully convicted individual is guilty (Zacharias, 2005). It may also stem from an interest in finality, or keeping the original decisions made by the criminal justice system intact, and therefore making prosecutors hesitant to charge another person for a crime that has already been tried in the system (Ginsburg \& Hunt, 2009; Kreimer \& Rudovsky, 2002; Medwed, 2004).

In general, this resistant behavior is likely the result of the psychological and structural factors at play in the criminal justice system that disincentivize prosecutors from cooperating with post-conviction claims of innocence (Medwed, 2004; O’Brien, 2009; Webster, 2019). New information that contradicts one's own sense of a situation presents a risk in that it challenges what is thought to be true, causing one to hold on to their original beliefs more strongly as a result (Lord, Ross, \& Lepper, 1979). In the present context, this tendency, known as confirmation bias, may cause prosecutors to discard new evidence of innocence in favor of their previously held beliefs in the innocent person's guilt (Burke, 2006; Findley \& Scott, 2006; Jonakait, 1987; Levenson, 2016). Their beliefs may be especially strong if years have passed since the exoneree was found guilty of the crime (Findley, 2008; Jonakait, 1987). Moreover, it is likely psychologically trying for a prosecutor, who is intended to act as a minister of justice, to have to revisit a case in which the result may indicate that they, or other members of their office, were involved in convicting an innocent person (Goldberg \& Siegel, 2002; Medwed, 2004; Schoenfeld, 2005). With the expectation that a prosecutor embodies a role in which they advocate for justice on behalf of the people (Berger v. United States, 1935), an overturned conviction based on the factual innocence of the wrongfully convicted party may cause members of the public to lose faith in their office (Green, 2019). Furthermore, if prosecutors agree to consider post-conviction claims of innocence, they risk offending other members of their "courtroom workgroup," with whom they must work closely and on a continuous basis (Webster, 2019). Cooperating with a post-conviction claim of innocence, or acknowledging it by charging an alternative perpetrator after an exoneration, may indicate to other members of the workgroup that they, too, participated in having an innocent person convicted of a crime they did not commit, potentially complicating future working relationships (Medwed, 2004; Zacharias, 2005).

\footnotetext{
${ }^{5}$ Members of a courtroom workgroup can include police, forensic analysts, informants, defense attorneys, judges and any other criminal justice actor who shares common goals and works with the prosecutor regularly (Eisenstein \& Jacob, 1977; Webster, 2019).
} 
Due to all of the above explained reasons, we posit that prosecutions of true perpetrators are, in some ways, fundamentally different from prosecutions of other offenders. Thus, we hypothesize that factors related to wrongful convictions in general are most likely to affect whether or not a true perpetrator is charged, just as we believe they will impact identifying true perpetrators. However, we still anticipate that the legal, equitable, and administrative considerations that impact prosecutors' decisions to charge other offenders might appear in their rationales not to charge a true perpetrator with the wrongful conviction offense(s). We test these hypotheses and those regarding identifying true perpetrators in three studies, detailed below.

\section{Current Studies}

Despite the importance of identifying and charging true perpetrators, the factors that influence these outcomes largely remain unknown. Therefore, the present works seek to determine if and how different factors impact whether or not a true perpetrator is identified, and whether or not an identified true perpetrator is charged with the wrongful conviction crime. Specifically, we aim to answer the following research questions:

1. What case factors affect whether or not a true perpetrator is identified?

2. For true perpetrators who have been identified, what case factors affect whether or not they are charged with the wrongful conviction offense(s)?

3. For true perpetrators who have been identified, what additional prohibitive and discretionary factors affect whether or not they are charged with the wrongful conviction offense(s)?

To answer these questions, we examined 367 wrong-person DNA exoneration cases and 161 unique true perpetrators. A full list of cases and true perpetrators, by criminal event, can be found in the Appendix.

\section{Study One: Identifying True Perpetrators}

\section{A. Data and Methods}

Data consisted of 367 wrong-person wrongful conviction cases. For the purposes of this study, a case is defined as a single individual who was exonerated for a crime they did not commit through DNA evidence. ${ }^{6}$ The data were provided by two leading innocence organizations; specifically, the 367 cases and some accompanying information were compiled by the Innocence Project, and matched with the public dataset from the National Registry of Exonerations ${ }^{7}$ website to include additional details for each case. The following factors, described below, serve as the independent variables for Study One.

\footnotetext{
${ }^{6}$ One criminal event may result in multiple cases. For example, the 367 DNA exoneration cases in our sample include each member of the Exonerated Five as an individual case, although they were all convicted of the same crime.

${ }^{7}$ Most recent data as of 2 February 2020.
} 


\section{Independent Variables}

Contributors to Wrongful Convictions. The contributors to wrongful convictions used for this study include: eyewitness misidentification, false confessions, perjury or falsified accusations, false or misleading forensic evidence, and inadequate legal defense, as defined and coded by the NRE (for definitions, see "Glossary," n.d.-b). Each of the contributors was classified as being either present or absent in each case. ${ }^{8}$

Prosecutorial Misconduct. ${ }^{9}$ Following previous work (Weintraub, 2020), summaries from the Innocence Project and NRE websites were qualitatively coded for evidence of actual or alleged prosecutorial misconduct. As systemic issues often cause the identification of prosecutorial misconduct at trial to be incomplete (Davis, 2009; West, 2010; West \& Meterko, 2015), data were collected in a variety of ways to ensure accuracy of the code. Specifically, cases were coded as containing prosecutorial misconduct if summaries mentioned information about a prosecutor failing to turn over material or impeachment evidence to the defense (Brady/Napue violations) or explicitly stated that the conviction was vacated based on prosecutorial misconduct (Brady $v$. Maryland, 1963; Napue v. Illinois, 1959). Afterwards, independent research was conducted utilizing: additional innocence databases (Gordon, 2003; Forejustice, 2018; Innocence Project, 2020; The Center for Public Integrity, 2003); academic sources (West \& Meterko, 2015); data sources for academic articles (West, 2010); and news stories of exonerations, all of which were qualitatively analyzed for similar constructs (e.g., Brady violations), and coded accordingly.

Most Severe Crime Type. Most severe crime type for a wrongful convictions case was coded using "worst crime display" as provided by the NRE public dataset.

High Volume Exoneration Counties. To control for counties that are over-represented in cases of wrongful convictions involving DNA exonerations (The National Registry of Exonerations, 2019), we included a variable to flag high volume exoneration counties. Following previous work (Weintraub, 2020), any county which had 6 or more cases in the sample was grouped into a category of high-volume wrongful conviction cases $(n=100)$. These counties included: Cook, IL $(n=39)$; Dallas, TX $(n=26)$; Harris, TX $(n=9)$; Jefferson, LA $(n=7)$; New York, NY $(n=7)$; Cuyahoga, $\mathrm{OH}(n=6)$; and Gage, NE $(n=6)$.

Assistance of an Innocence Organization. As innocence organizations have additional tools and resources that are not available to lay people trying to prove their own innocence, we accounted for whether or not an innocence organization assisted in a wrongful conviction case. Assistance of an innocence organization was coded and defined by the NRE (see "Glossary," n.d.b).

Crime Occurrence Before or After 1989. Convictions that resulted in DNA-based exonerations and occurred before the advent of modern DNA science are likely qualitatively different than those that occurred after. The use of DNA technology in the context of U.S. exonerations did not begin until approximately 1989 (Gross \& Shaffer, 2012), so cases were

\footnotetext{
${ }^{8} 213(58 \%)$ cases had more than one contributor.

9 We coded prosecutorial misconduct as a substitute for the "official misconduct" variable provided by the NRE. Correspondence with a researcher at the NRE revealed that cases may be coded as both official misconduct and "false or misleading forensic evidence" for the same actions (Maurice Possley, personal communication, 13 October 2017). Thus, the substitution was made to avoid multicollinearity between these two variables.
} 
broken into two groups and coded dichotomously based on the year of conviction provided the Innocence Project: convicted before 1989 and convicted in or after 1989.

Race. The pervasive cultural stereotypes in the U.S. linking Black individuals and criminality (Blair, Judd \& Fallman, 2004; Devine, 1989), as well as the fact that Black individuals are more easily dehumanized and are seen as more culpable for their actions than their White counterparts (Goff et al., 2014), have contributed to racially disparate outcomes in the criminal justice system. Specifically, Black offenders receive harsher and longer sentences, and are more likely to be sentenced to death in capital cases, than White offenders (Eberhardt et al., 2006; Viglione, Hannon, \& DeFina, 2011). This pattern is further exacerbated when the victim of a Black offender is White (Eberhardt et al., 2006). To determine if there is a similar effect of race on outcomes for true perpetrators, the race of the wrongfully convicted individual and victim were coded as: (1) a Black exoneree and victim; (2) a White exoneree and victim; (3) a Black exoneree and White victim; or (4) a White exoneree and Black victim. ${ }^{10}$

\section{Dependent Variable}

True Perpetrator Identification. Cases were defined as having an identified true perpetrator in one of two ways based on data provided by the Innocence Project. First, if the true perpetrator was discovered via a "database hit," in which the DNA profile from the crime scene or victim matched to a previously unknown suspect in the database). Second, if the true perpetrator who committed the crime was identified by a "direct comparison," meaning the DNA profile was compared against that of an alternate suspect instead of a database. A dichotomous variable was created to indicate whether or not a true perpetrator was identified in one of these manners (see Table 1).

Table 1. Frequencies of Independent Variables by True Perpetrator Identification

\begin{tabular}{|c|c|c|c|c|c|c|c|}
\hline & & \multicolumn{2}{|c|}{$\begin{array}{l}\text { No True } \\
\text { Perpetrator } \\
\text { Identified }\end{array}$} & \multicolumn{2}{|c|}{$\begin{array}{l}\text { True } \\
\text { Perpetrator } \\
\text { Identified }\end{array}$} & \multicolumn{2}{|c|}{ Total } \\
\hline & & $\bar{n}$ & $\%$ & $n$ & $\%$ & $n$ & $\%$ \\
\hline \multirow{2}{*}{ False Confession } & No & 156 & $86 \%$ & 124 & $67 \%$ & 280 & $76 \%$ \\
\hline & Yes & 26 & $14 \%$ & 61 & $33 \%$ & 87 & $24 \%$ \\
\hline \multirow{2}{*}{$\begin{array}{l}\text { Mistaken Witness } \\
\text { Identification }\end{array}$} & No & 35 & $19 \%$ & 88 & $48 \%$ & 123 & $34 \%$ \\
\hline & Yes & 147 & $81 \%$ & 97 & $52 \%$ & 244 & $67 \%$ \\
\hline \multirow{2}{*}{ Perjury/False Accusation } & No & 127 & $70 \%$ & 91 & $49 \%$ & 218 & $59 \%$ \\
\hline & Yes & 55 & $30 \%$ & 94 & $51 \%$ & 149 & $41 \%$ \\
\hline
\end{tabular}

\footnotetext{
${ }^{10}$ Some research (e.g., Platz \& Hosch, 1988; Teitelbaum \& Geiselman, 1997) has examined how those of Hispanic /Latinx ethnicity compare to Black individuals regarding criminality and outcomes in the criminal justice system. However, due to the limited research on the topic and very few cases $(n=26)$ in our dataset, these cases were not coded for race in the analysis.
} 


\begin{tabular}{|c|c|c|c|c|c|c|c|}
\hline \multirow{2}{*}{$\begin{array}{l}\text { False/Misleading Forensic } \\
\text { Evidence }\end{array}$} & No & 100 & $55 \%$ & 110 & $60 \%$ & 210 & $57 \%$ \\
\hline & Yes & 82 & $45 \%$ & 75 & $41 \%$ & 157 & $43 \%$ \\
\hline \multirow{2}{*}{ Inadequate Legal Defense } & No & 164 & $90 \%$ & 167 & $90 \%$ & 331 & $90 \%$ \\
\hline & Yes & 18 & $10 \%$ & 18 & $10 \%$ & 36 & $10 \%$ \\
\hline \multirow{2}{*}{ Prosecutorial Misconduct ${ }^{\mathrm{a}}$} & $\mathrm{No}$ & 114 & $71 \%$ & 139 & $77 \%$ & 253 & $74 \%$ \\
\hline & Yes & 47 & $29 \%$ & 41 & $23 \%$ & 88 & $26 \%$ \\
\hline \multirow{10}{*}{ Most Severe Crime Type } & Accessory to Murder & 0 & $0 \%$ & 1 & $1 \%$ & 1 & $<1 \%$ \\
\hline & Attempted Murder & 2 & $1 \%$ & 1 & $1 \%$ & 3 & $1 \%$ \\
\hline & $\begin{array}{l}\text { Attempted Violent } \\
\text { Crime }\end{array}$ & 0 & $0 \%$ & 1 & $1 \%$ & 1 & $<1 \%$ \\
\hline & $\begin{array}{l}\text { Burglary/Unlawful } \\
\text { Entry }\end{array}$ & 0 & $0 \%$ & 1 & $1 \%$ & 1 & $<1 \%$ \\
\hline & Child Sex Abuse & 18 & $10 \%$ & 8 & $4 \%$ & 26 & $7 \%$ \\
\hline & Kidnapping & 1 & $1 \%$ & 3 & $2 \%$ & 4 & $1 \%$ \\
\hline & Murder & 41 & $23 \%$ & 93 & $50 \%$ & 134 & $37 \%$ \\
\hline & Robbery & 3 & $2 \%$ & 7 & $4 \%$ & 10 & $3 \%$ \\
\hline & Sexual Assault & 117 & $64 \%$ & 69 & $37 \%$ & 186 & $51 \%$ \\
\hline & $\begin{array}{l}\text { Weapon Possession } \\
\text { or Sale }\end{array}$ & 0 & $0 \%$ & 1 & $1 \%$ & 1 & $<1 \%$ \\
\hline \multirow{2}{*}{$\begin{array}{l}\text { High Volume Exoneration } \\
\text { Counties }\end{array}$} & Low Volume & 141 & $78 \%$ & 126 & $68 \%$ & 267 & $73 \%$ \\
\hline & High Volume & 41 & $23 \%$ & 59 & $32 \%$ & 100 & $27 \%$ \\
\hline \multirow{2}{*}{$\begin{array}{l}\text { Assistance of an Innocence } \\
\text { Organization }\end{array}$} & $\mathrm{No}$ & 96 & $53 \%$ & 96 & $52 \%$ & 192 & $52 \%$ \\
\hline & Yes & 86 & $47 \%$ & 89 & $48 \%$ & 175 & $48 \%$ \\
\hline \multirow{2}{*}{$\begin{array}{l}\text { Crime Occurrence Before } \\
\text { or After } 1989\end{array}$} & Before 1989 & 126 & $69 \%$ & 101 & $55 \%$ & 227 & $62 \%$ \\
\hline & After 1989 & 56 & $31 \%$ & 84 & $45 \%$ & 140 & $38 \%$ \\
\hline \multirow{3}{*}{ Race $^{b}$} & $\begin{array}{l}\text { White Exoneree \& } \\
\text { Victim }\end{array}$ & 48 & $37 \%$ & 40 & $27 \%$ & 88 & $32 \%$ \\
\hline & $\begin{array}{l}\text { Black Exoneree \& } \\
\text { Victim }\end{array}$ & 32 & $25 \%$ & 34 & $23 \%$ & 66 & $24 \%$ \\
\hline & $\begin{array}{l}\text { White Exoneree \& } \\
\text { Black Victim }\end{array}$ & 1 & $1 \%$ & 2 & $1 \%$ & 3 & $1 \%$ \\
\hline
\end{tabular}


Black Exoneree \&

$\begin{array}{lllllll}\text { White Victim } & 48 & 37 \% & 70 & 48 \% & 118 & 43 \%\end{array}$

${ }^{a}$ Twenty-six cases were not coded for prosecutorial misconduct because there was a possibility that prosecutors committed misconduct, but the circumstances of the case made it unclear (e.g., a state forensic analyst misrepresented evidence that may or may not have been known to the prosecution).

${ }^{b}$ Ninety-two cases were not coded for race because either the race of the victim or exoneree could not be determined, there were multiple victims of different races, or the exoneree or victim were Hispanic/Latinx.

\section{B. Results}

A logistic regression analysis specified the relations between the described independent variables and the odds of identifying $(n=185)$ versus not identifying $(n=182)$ the true perpetrator (see Table 2). The model was statistically significant $\chi^{2}(13)=53.98, p<.001$, Nagelkerke $R^{2}=$ .27), supporting our hypothesis that these factors impact the odds of identifying a true perpetrator. Specifically, prosecutorial misconduct was significantly and negatively associated with the odds of identifying a true perpetrator. The odds of a true perpetrator being identified were more than twice as likely for cases in which prosecutorial misconduct was not a contributing factor to the wrongful conviction than for cases in which it was $(B=-0.71, p=.04, O R=0.49)$.

Also significantly associated with the odds of identifying a true perpetrator was most severe crime type $\left(\chi^{2}(2)=10.12, p=.01\right)$. Specifically, the odds of identifying a true perpetrator were almost five times greater when the most severe crime type was murder than when the most severe crime type was child sexual abuse $(B=-1.56, p=.03, O R=0.21)$. Similarly, the odds of identification were nearly four times greater when the most severe crime type the exoneree was convicted of was murder compared to sexual assault $(B=-1.35, p<.01, O R=0.26)$.

Lastly, race of the exoneree and victim was significantly associated with the odds of identifying a true perpetrator $\left(\chi^{2}(2)=12.57, p<.01\right)$. Specifically, compared to cases in which the exoneree and victim were both White, the odds of a true perpetrator being identified were $244 \%$ greater when the exoneree was Black and the victim was White $(B=1.24, p<.01, O R=3.44)$. There was no significant difference in the odds of identifying the true perpetrator if the exoneree and victim were both Black $(B=0.16, p=.69, O R=1.18)$ as compared to when the exoneree and victim were both White. Contrary to our hypothesis, none of the other contributors to wrongful convictions, nor high volume exoneration county, assistance of an innocence organization, or crime occurrence before or after 1989 were significantly associated with the odds of identifying a true perpetrator (all $p \mathrm{~s} \geq .16$ ). 
Table 2. Logistic Regression Analysis of True Perpetrator Identification

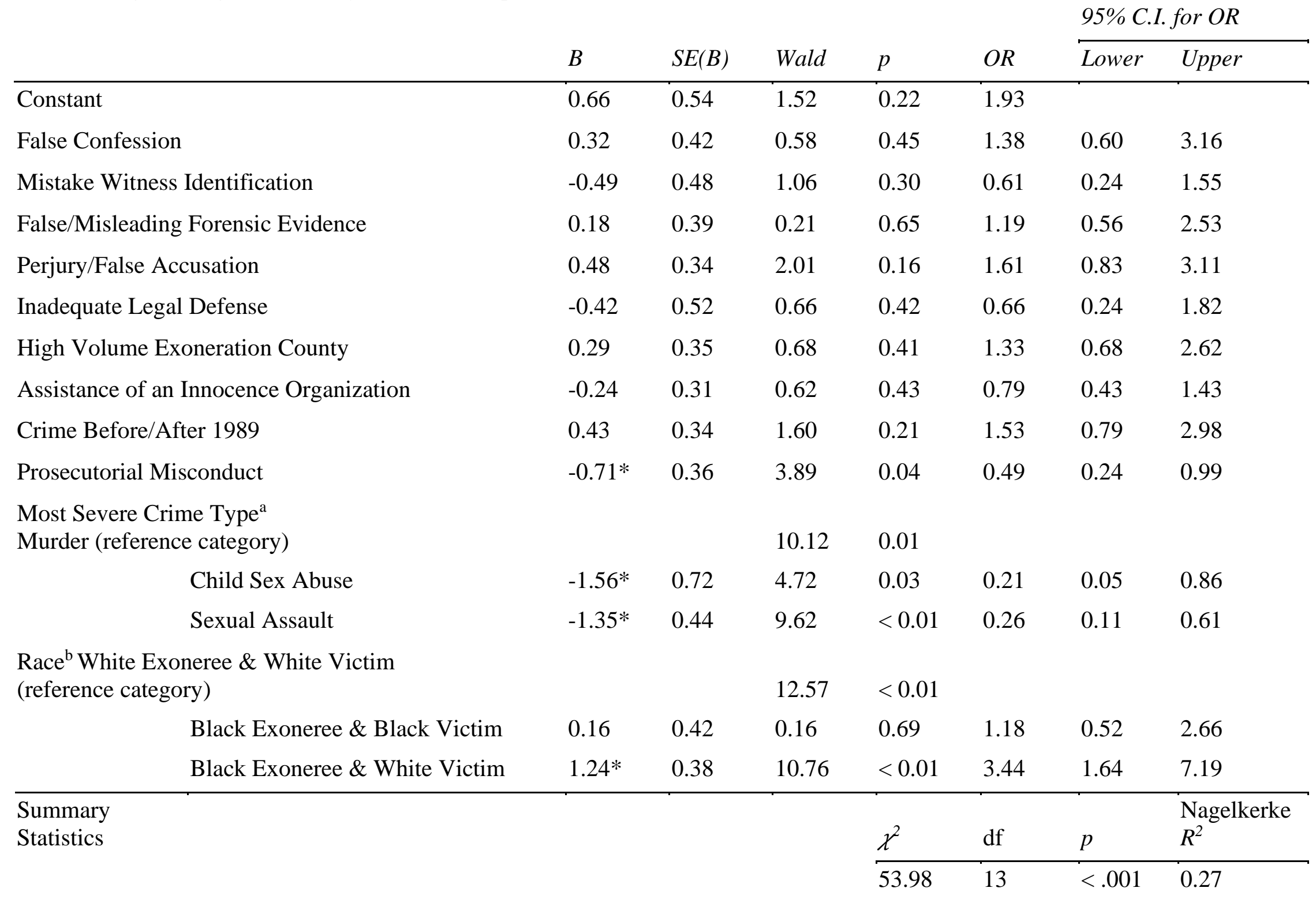


Accessory to Murder, Attempted Murder, Attempted Violent Crime, Burglary/Unlawful Entry, Kidnapping, Robbery, and Weapon Possession or Sale were dropped from the model as there were either 0 or 1 case(s) in one of the outcomes.

$\mathrm{b}$ White exoneree and Black victim was dropped from the model as there was only one case in one of the outcomes.

$* p<.05$

\section{Discussion}

We found that prosecutorial misconduct, most severe crime type, and the race of the defendant and the victim all significantly impacted the probability of identifying a true perpetrator. In line with prior research (Weintraub, 2020), prosecutorial misconduct was found to be negatively associated with the odds of identifying a true perpetrator. As previously discussed, prosecutors historically do not cooperate with the majority of post-conviction innocence claims (Webster, 2019), especially in high-stakes cases such as those with prosecutorial misconduct (Bowman \& Gould, 2020). Therefore, prosecutors may be more inclined to object to post-conviction petitions for DNA testing - the mechanism which would identify a true perpetrator in these DNA exoneration cases - if prosecutorial misconduct was present at trial. And, because courts often put a great deal of emphasis on the prosecutor's recommendation in post-conviction DNA petitions (Ginsburg \& Hunt, 2009; Green \& Yaroshefsky, 2009; Kreimer \& Rudovsky, 2002; Medwed, 2004), their opposition could prohibit the identification of a true perpetrator.

Additionally, psychological factors that originally caused a prosecutor to commit misconduct at trial can carry over beyond the trial stage and result in an unwillingness to help identify a true perpetrator post-conviction (Jonakait, 1987; O’Brien, 2009; Yaroshefsky, 2013). A prosecutor's belief in an innocent person's guilt at trial, whether founded or not, can cause them to pursue an innocent individual to the point of committing acts of misconduct (Schoenfeld, 2005). After having gone to such lengths to have the wrongfully convicted person found guilty, it is likely more difficult to combat this belief even when faced with evidence to the contrary post-conviction. This tunnel vision on the wrongfully convicted person can translate into a resistance or refusal to cooperate with the necessary steps to identify the true perpetrator, like the post-conviction DNA petitions mentioned above (Jonakait, 1987; O'Brien, 2009). Moreover, concerns about losing the public's confidence can be amplified if in addition to the wrongful conviction, a prosecutor's act of misconduct directly contributed to that wrongful conviction (Kreimer \& Rudovsky, 2002; Orenstein, 2011).

Compared to a case having the most severe crime type of murder, the true perpetrator was less likely to be identified if the most severe crime type was child sex abuse or sexual assault. One reason for this may be the inclusion of a vulnerable victim in child sex abuse and sexual assault cases that is not present in murder cases. Most experts agree that the trauma and stigma surrounding sexual abuse and assaults not only cause significant underreporting by victims, but also a fear of being revictimized by the investigation and prosecution (see Brody \& Acker, 2015). Thus, although one reason for bringing charges against true perpetrators is to get justice for the victims, prosecutors may be less willing to reinvestigate an exoneration case for fear of upsetting or retraumatizing the victims of sexual assault or abuse, especially if the cases involve children. 
Race of the victim and exoneree was also shown to be a significant factor in the outcome of true perpetrator identification, as it is in other areas of criminal justice. In the current context, the odds of identifying a true perpetrator were much greater when the exoneree was Black and the victim was White, compared to when the exoneree and victim were both White. However, the odds of identification were no different when the offender and victim were both Black, compared to when they were both White. These findings are in line with research on sentencing outcomes, especially in capital cases, where the outcome is the worst for the offender when the offender is Black and the victim is White (e.g., Eberhardt et al., 2006). Although identifying true perpetrators is a positive outcome, thus appearing contradictory to such previous research, these results are logical when viewed through the lens of the true perpetrator, for whom being identified is a negative outcome. Viewing these results through this lens also clarifies the found relation between race and true perpetrator identification. It is likely that finding the true perpetrators in cases with a Black exoneree and White victim is considered more important to prosecutors, as Black offenders are seen as more culpable for their actions and White victims are not dehumanized in the way Black individuals can be (Goff et al., 2014), thus increasing the odds of identification. Moreover, research has shown that implicit biases, rooted in broad cultural stereotypes, affects prosecutorial discretion at every decision-point (Smith \& Levinson, 2012). Thus, it is likely that together, these circumstances increase the odds of identifying a true perpetrator if the accused is Black.

Although identifying true perpetrators is important for understanding the consequences of wrongful convictions, public safety and justice require them to then be charged for their crimes. Having established which of the hypothesized factors impact the identification of true perpetrators, the next step is to test their effect on charging. Study Two aims to achieve this by examining if and how these factors impact the odds of charging identified true perpetrators.

\section{Study Two: Charging True Perpetrators}

\section{A. Data and Methods}

To examine the factors that affect the charging of a true perpetrator, the unit of analysis was changed from exoneration case to an identified true perpetrator. Each true perpetrator who actually committed the crimes that the individual in the case was wrongfully convicted of was identified as a single observation. For the cases in which no true perpetrator was identified, the number of true perpetrators was assumed to be one unless otherwise specified by the Innocence Project or National Registry of Exonerations (e.g., if multiple DNA profiles were identified). Duplicate cases, where one true perpetrator was named for multiple exonerees in one criminal event, were dropped from the dataset. Of the estimated 344 unique true perpetrators, 161 were identified by name or DNA and thus the state had the necessary information to potentially charge them. Each of these 161 identified true perpetrators was coded for whether or not they were charged with the wrongful conviction crime. Eleven observations were dropped from our analyses, as there was not sufficient information (e.g., a name) to verify whether or not the true perpetrator had been charged. One additional identified true perpetrator was dropped because, as of this 
writing, he had been arrested but not yet charged. Thus, the final dataset consisted of 149 unique, identified true perpetrators. ${ }^{11}$

\section{Independent Variables}

All of the independent variables from Study One were utilized in the current study (i.e., contributors to wrongful convictions, most severe crime type, high volume exoneration counties, assistance of an innocence organization, crime occurrence before or after 1989, and race).

\section{Dependent Variable}

Charging Identified True Perpetrators. Observations were coded as to whether or not an identified true perpetrator was charged for the crimes for which the exoneree was convicted. ${ }^{12}$ Identified true perpetrators were defined as having been charged if information from the Innocence Project, National Registry of Exonerations, and news stories about the exonerations of the wrongfully convicted individual indicated that the true perpetrator had been charged. Thus, a dichotomous variable was created to indicate whether or not an identified true perpetrator was charged with the wrongful conviction crime.

\section{B. Results}

A logistic regression analysis specified the relations between the described independent variables and the odds of charging $(n=75)$ versus not charging $(n=74)$ an identified true perpetrator with the wrongful conviction crime. The model was not statistically significant $\left(\chi^{2}(17)\right.$ $=25.87, p=.08$ ), indicating that all together, the independent variables are not associated with the odds of charging an identified true perpetrator. This finding is contrary to our hypothesis that factors relevant to wrongful convictions and criminal justice outcomes broadly would also be influential in whether or not a true perpetrator was charged with the wrongful conviction crime.

\section{Discussion}

We did not find that our independent variables are associated with the odds of charging an identified true perpetrator, indicating that the factors underlying true perpetrator identification and charging decisions appear to differ from one another. This may be due to the different roles prosecutors play in identifying versus charging true perpetrators. Although prosecutors participate in the post-conviction processes which can identify a true perpetrator in DNA exoneration cases, such as providing recommendations regarding post-conviction petitions for DNA testing (Ginsburg \& Hunt, 2009; Green \& Yaroshefsky, 2009), handling these petitions is not necessarily within their daily job duties. Conversely, the decision of whether or not to charge an offender is exactly within the typical duties of a prosecutor (Albonetti, 1987; Jacoby, 1980), even if some of the circumstances surrounding true perpetrator cases are less common. Therefore, it is likely that reasons affecting a prosecutor's ability and willingness to bring charges against any offender also

\footnotetext{
${ }^{11}$ One true perpetrator, Walter Ellis, is included twice in this analysis as he is the true perpetrator of two separate wrongful convictions criminal events, involving different groups of exonerees (see Appendix).

${ }^{12}$ We specifically chose to examine whether or not a true perpetrator was charged as opposed to convicted because the goal of this analysis was to examine if the state even sought justice in charging the true perpetrator. Additionally, using conviction of the true perpetrator as the outcome variable would have required additional considerations such as charge bargaining and jury decision-making, which were not the focus of the current study.
} 
impact the decision to bring charges against a true perpetrator. Study Three explores whether the reasons prosecutors may resist post-conviction innocence claims, and similar rationales to those proffered by prosecutors in non-true perpetrator cases, appeared throughout cases where the prosecutor did not charge an identified true perpetrator with the wrongful convictions crime.

\section{Study Three: Exploring Cases of Uncharged True Perpetrators}

\section{A. Data and Methods}

To determine the factors that may have impacted the decision not to charge an identified true perpetrator, the sample was limited to the unique true perpetrators who were identified but not charged with the wrongful conviction crime(s) $(n=74)$. Using data from the Innocence Project, National Registry for Exonerations, court documents, and publicly available sources such as news articles and media reports, and books, we conducted a qualitative content analysis to identify categories or themes that emerged regarding the decision not to charge an identified true perpetrator (Cho \& Lee, 2014; Moretti, van Vliet, Bensing, et al., 2011). Specifically, each author individually conducted open coding to identify potential patterns in the data and grouped these patterns based on construct relatedness. After completing this coding, we discussed the identified patterns together and created a codebook. ${ }^{13}$ Closed coding was then completed independently in accordance with the codebook. Our codes were then compared, and discrepancies addressed and resolved via discussion.

Seven factors were identified that could be categorized into two mutually exclusive groups, which we termed "definitively prohibitive" and "potentially influential" factors in the charging decision. Each identified true perpetrator was coded for if the definitively prohibitive and potentially influential factors were absent or present. For cases in which none of the identified codes were present, and for which no other factors were identified, "unknown" was coded.

Definitely Prohibitive Factors. Definitively prohibitive factors were defined as reasons why a prosecutor could not charge an identified true perpetrator with the wrongful conviction crime(s). Two non-mutually exclusive factors fit this definition: death and expiration of statutes of limitations. In these cases, a prosecutor was definitively prohibited from charging the true perpetrator either because that individual had died, or the law prohibited such action.

Death. Death was coded if it was determined that the true perpetrator died before the exoneration of the wrongfully convicted person.

Statutes of Limitations. Statutes of limitations are "a statutory limitation on the prosecution of an offense if the formal prosecution is not commenced, usually by return of an indictment or filing of an information, within a specified period after the completion of the offense" (U.S. Dept. of Justice, 2020). To code for whether or not a statute of limitations was a definitively prohibitive factor, we first identified the top charge (or specific most severe crime) that each exoneree was convicted of based off of the most severe crime type. Top charge was identified using the same

\footnotetext{
${ }^{13}$ Each codebook item is described in the following subsections and listed in Table 3.
} 
sources as previously used in Study One and Study Two (e.g., the Innocence Project, the National Registry of Exonerations, court documents, media reports, etc.). If the specific crime could not be identified, top charge was coded as the most serious crime that could be defined under the most severe crime type. For example, if an exoneree was convicted of "sexual assault" and no specific charge could be found, the most serious sexual assault offense was identified in the state's penal code (e.g., "aggravated rape with a deadly weapon") and coded as the top charge for that true perpetrator. Using the top charge allowed us to be conservative in our estimates of whether true perpetrators would be prohibited from being charged due to an expired statute of limitations by coding for the longest possible statute of limitation they could have faced, and thus providing the best opportunity for the true perpetrator to be charged.

Once top charge was identified, information from the accompanying statute of limitations was coded for each offense by researching each state's specific penal codes. Specifically, we recorded the time at which the statute of limitations clock begins (e.g., at the time of the crime, time of arrest, etc.) and the length of the statute of limitations in years. We then compared the date the statutes of limitations expired to the date the wrongfully convicted individual was exonerated to determine if the statute expired before the exoneree was released, thus prohibiting prosecutors from charging the true perpetrator.

Potentially Influential Factors. In addition to the definitively prohibitive factors, we identified five non-mutually exclusive reasons why a prosecutor might not have charged the identified true perpetrators: incarceration, guilt, evidence, embarrassment, and psychiatric incapacitation. Each factor was coded as present or absent for each identified true perpetrator.

Incarceration. In some cases, prosecutors may have chosen not to charge the identified true perpetrator because they were already incarcerated for another crime, even though there is no law prohibiting them from doing so. Incarceration was coded as a potentially influential factor if the identified true perpetrator was incarcerated at the time of the exoneration, or if one of the aforementioned sources indicated incarceration as part of the prosecutor's discretionary process. For example, one source read: "[the true perpetrator], it turns out, was serving time in the same prison for the rape of a woman in the same apartment complex as the victim assaulted in [exoneree's] case" (Greene, 2007). To determine the incarceration status of the true perpetrator, true perpetrators were searched on states' Department of Corrections websites, as well as searching the aforementioned sources for reports of incarceration, following previous work (see Norris, Weintraub, et al., 2019).

Guilt. Prosecutors are bound by ethical standards that require them not to proceed with charges against an individual if belief in their guilt beyond a reasonable doubt is lacking (Gershman, 2010). Thus, guilt was coded as present for any cases in which the decision not to charge the identified true perpetrator was potentially influenced by a belief on the part of the prosecutor that the exoneree was still guilty. For example, after one exoneration by DNA, the prosecutor still "continue[d] to investigate whether he [the exoneree] has any connections to [the victim]" (Emch, 2001, para. 25).

Evidence. Evidence refers to a subjective concern on the part of the prosecutor that although the true perpetrator was identified, there was not enough evidence to charge them with 
the wrongful conviction crime. Evidence was coded as a potentially influential factor if a source indicated that prosecutors stated that this was a concern of theirs, regardless of how objectively strong or weak the evidence was.

Embarrassment. Embarrassment was coded as present for cases in which the decision not to charge the identified true perpetrator was indicated to have been influenced by embarrassment on the part of the prosecutor. For example, in writing about one wrongful conviction case, the news reported that the prosecutor's "rationale for not prosecuting...is known only to her, but a decision to prosecute the case would certainly have created embarrassment for [the Assistant District Attorney]" (Warden, 2015, para. 9).

Psychiatric Incapacitation. Similar to incarceration, psychiatric incapacitation was coded as a potentially influential factor if it was determined, using publicly available data, that the identified true perpetrator was residing in a psychiatric facility when the exoneree was released.

\section{B. Results}

Of the 74 true perpetrators who were identified but not charged, there was a definitively prohibitive factor for $25(34 \%)$ of them. Ten (14\%) identified true perpetrators died before the exoneree was released, and therefore were not charged with the wrongful conviction crime. Thirteen (18\%) identified true perpetrators could not be charged because the statute of limitations for the top charge wrongful conviction crime had expired by time the exoneree was released. For two (3\%) additional identified true perpetrators, the statute of limitations would have prohibited being charged, but the true perpetrator died before the exoneree was released (see Table 3 ).

Table 3. Frequencies of Definitively Prohibitive and Potentially Influential Factors

\begin{tabular}{lll} 
Definitively Prohibitive Factors $(n=25)$ & $n$ & $\%$ \\
\hline Death & 10 & $40 \%$ \\
Statute of Limitations & 13 & $52 \%$ \\
Death and Statute of Limitations & 2 & $8 \%$ \\
\hline Total & 25 & $100 \%$
\end{tabular}

Potentially Influential Factors $(n=49)^{\mathrm{a}}$

\begin{tabular}{lll}
\hline Unknown & 25 & $51 \%$ \\
\hline Incarceration & 20 & $41 \%$ \\
Guilt & 4 & $8 \%$ \\
Evidence & 3 & $6 \%$ \\
Embarrassment & 1 & $2 \%$ \\
Psychiatric Incapacitation & 1 & $2 \%$
\end{tabular}

${ }^{a}$ Cases were coded either as Unknown, or with at least one potentially influential factor. Because these factors were not mutually exclusive, the total exceeds $100 \%$. 
The 25 individuals who were coded with a definitely prohibited factor were then removed from the analysis, and the remaining 49 (66\%) identified true perpetrators were examined for potentially influential factors. Incarceration was the most common potentially influential factor, occurring in $20(41 \%)$ of these cases. Guilt was a potential factor in four (8\%) cases, and evidence was a potential factor in three $(6 \%)$ cases. Finally, embarrassment and psychiatric incapacitation were both potential factors in just one $(2 \%)$ case. For nineteen $(39 \%)$ identified true perpetrators, only one potentially influential factor was identified, and for five (10\%) identified true perpetrators, two of these factors were identified. For the remaining $25(51 \%)$ identified true perpetrators, no potentially influential factors were identified (see Table 3 ).

\section{Discussion}

This exploratory study uncovered a variety of reasons that potentially or decisively caused the prosecutor not to charge the true perpetrator for the wrongful conviction crime(s). Across all of the cases and both the definitively prohibitive and potentially influential factors, one of the most prominent factors affecting charging an identified true perpetrator was an expired statute of limitations. Despite using the most conservative estimates, statutes of limitations still affected $20 \%$ of all identified true perpetrators. ${ }^{14}$ That is, in these cases the statute of limitations had expired by the time the wrongfully convicted person was exonerated, thus eliminating the possibility for these true perpetrators to be charged. It is important to emphasize, again, that this percentage represents the least possible number of true perpetrators who could be protected from charges due to an expired statute of limitations, as only the least restrictive statute for the most serious crime was analyzed. ${ }^{15}$ Further, 96 (59\%) of the identified true perpetrators in the sample could have faced charges for more than one crime. ${ }^{16}$ Given that these additional lesser crimes likely had more restrictive statutes of limitations which would have expired earlier than the single top charge coded, our estimate of how often an expired statute of limitations prohibited the prosecutor from charging the true perpetrator with a wrongful conviction crime is an underestimate. Additionally, the expiration of a statute of limitations was only explored for the identified true perpetrators who were not charged. For just the data examined herein, there are, at minimum, an additional 182 true perpetrators who were not identified and may be similarly protected from being charged with the wrongful convictions crime by expired statutes of limitations. Furthermore, this study only examines the effect of statutes of limitations in 367 DNA exoneration cases; however, there are an estimated 2,247 additional exonerations ("National Registry of Exonerations," 2020). ${ }^{17}$ Extrapolating from the conservative estimates of the current results, wherein $20 \%$ of true perpetrators were affected by statutes of limitations, that is an additional 450 true perpetrators, who could have escaped culpability for their crimes due to statutory restrictions.

The leading potentially influential factor in the decision to charge identified true perpetrators for the wrongful convictions crime(s) was incarceration. Although there is no legally

\footnotetext{
${ }^{14}$ Defined as the thirteen individuals for whom the statute of limitations expired in addition to the two individuals who died but for whom statutes of limitations would have been prohibitive regardless.

${ }^{15}$ To this point, by changing the definitions for the top charges that could not be identified from the most serious to the least serious crime that could be defined in the most severe crime type, an expired statute of limitations becomes prohibitive in $31 \%$ of cases.

${ }^{16}$ Counts of how many charges a true perpetrator could have faced are based on how many crimes the wrongfully convicted person was convicted of.

${ }^{17}$ Most recent data are as of 2 February 2020.
} 
prohibitive obstacle to doing so, prosecutors appeared to have an aversion to charging someone who was already incarcerated for a different offense. This may be due to the equitability or administrative considerations, as it would not necessarily serve the public or be a good use of resources to charge someone who is already incapacitated from committing another crime. A similar equitability argument can be made for psychiatric incapacitation, in which prosecutors may have believed that the psychiatrically incapacitated ought not be charged for their crimes in the name of justice. However, convicting these true perpetrators for the wrongful convictions crimes could add more time to their sentences, simultaneously protecting society and further punishing that individual for their additional crimes. Even for cases where the true perpetrator had already been permanently removed from society, convicting them of the wrongful conviction crime(s) could also provide closure to both the victim and exoneree. This was the case for Leon Davis, the true perpetrator of the crimes in Thomas Haynesworth's case. When investigations began into Haynesworth's innocence, Davis was already serving multiple sentences of life imprisonment for the crimes he continued to commit after Haynesworth was wrongfully incarcerated (Acker, 2013; Green, 2009). In such cases, the goal of charging the true perpetrator would be to help heal the innocents affected by the crime and wrongful conviction, as opposed to simply punishing the guilty.

Several of the other potentially influential factors we found (i.e., embarrassment, guilt, and evidence) fit with the previously discussed psychological and structural factors which may cause prosecutors to be uncooperative with post-conviction innocence claims. For instance, concerns about their own involvement in a wrongful conviction, and perceptions from the public and their courtroom workgroup, may cause embarrassment that dissuades prosecutors from charging the true perpetrator. Additionally, confirmation bias likely affects both a prosecutor's belief that the wrongfully convicted individual is still guilty of the crimes, an equitability consideration, and the belief that there is not enough evidence to charge the true perpetrator, in line with the legal considerations for not charging a perpetrator. ${ }^{18}$ In both cases, the previously held belief of the exoneree's guilt would overpower any new information indicating their innocence and the guilt of another.

As the first of its kind, the findings uncovered in this work only begin to scratch the surface of factors that affect outcomes for true perpetrators' identification and charging for the wrongful convictions crime. But it provides a plethora of directions for future research, and sheds light on potential policy implications, both of which are discussed next.

\section{General Discussion}

The current studies serve as a first step to examining why true perpetrators are or are not identified and subsequently charged with the crimes they committed and for which someone else was wrongfully convicted. We discovered that though some case factors related to wrongful convictions impacted the odds of true perpetrator identification, the decision to charge a true perpetrator with the wrongful conviction crime was instead associated with the reasons prosecutors

\footnotetext{
${ }^{18}$ It is important to note, again, that "evidence" was coded if any sources indicated that the prosecutor was hesitant about the strength of the evidence against the true perpetrator. This was a subjective code based on the prosecutors' belief, and not any objective measure of the strength of the evidence.
} 
press charges on perpetrators more broadly, and how they process post-conviction claims of innocence. Of the findings herein, the most actionable is that regarding the role of statutes of limitations in prohibiting prosecutors from charging true perpetrators. Especially for cases in which the true perpetrator has not yet been identified, the length of imprisonment of the wrongfully convicted individual will likely exceed the corresponding statute of limitations. Statutes of limitations were originally implemented to protect defendants due process rights by ensuring the availability of evidence and that the adjudication of such matters occurred diligently and swiftly (United States v. Lovasco, 1977). However, in cases of wrongful convictions, this long-standing precedent fails. In all cases of wrongful convictions, not only has an innocent individual suffered an unjust loss of liberty, but the true perpetrators cannot be held legally responsible.

One potential solution, which has been adopted by at least 27 states, is to create DNA exceptions to statutes of limitations (Rape, Abuse \& Incest National Network, 2012). These exceptions, broadly, can suspend or extend statutes of limitations in cases where DNA evidence identifies the actual perpetrator of a crime (End the Backlog, "Statute of Limitations," n.d.). However, these statutes are not perfect; they are often limited to only include some offenses (e.g., Ga. Code $\S 17-3-2.1$ ), or only to change the length of time before the statute of limitations expires instead of removing it entirely (see N.J. Stat. § 2C:1-6; Ohio Rev. Code Ann. § 2901.13). These caveats still allow a true perpetrator to escape being charged for the wrongful conviction crimes. Extending or eliminating statutes of limitations entirely in cases of wrongful convictions could create a clearer path for prosecutors to seek justice for the victims of the true perpetrators and those wrongfully convicted for their crimes.

\section{Limitations and Future Directions}

These studies are not without their limitations. The data were constricted to wrongful conviction cases in which the exoneree was exonerated by DNA, as defined by the Innocence Project. However, the NRE currently reports over 2,000 additional exonerations which do not fit this definition and thus are not included in the Innocence Project's database ("National Registry of Exonerations," 2020). It is possible that exonerations compiled by the Innocence Project, and analyzed here, are qualitatively different than others, and thus the factors that affect the identification and charging of true perpetrators in these cases are qualitatively different as well. Due to these reasons, we hesitate to extrapolate our findings beyond exonerations based on DNA evidence.

In addition, we cannot be certain that the factors we identified in Study Three as potentially influential factors in the decision to charge true perpetrators were in fact the reasons prosecutors failed to do so. Our judgments were based upon what was reported and quoted by secondary sources and may not accurately reflect the actual reasons for a prosecutor's discretionary judgments. Furthermore, although we were exhaustive in coding for definitively prohibitive and potentially influential factors, no such factors were found for a full $51 \%$ of the subsample. But this number does not necessarily indicate a lack of such factors for these cases. We only coded for the listed variables if there was an explicit indication of the concept in a public or obtained source. There are likely several additional factors, both conscious and subconscious, that influence a prosecutor's decision to charge an identified true perpetrator that would not be found in such limited public sources. To dig deeper into these factors, future research should consider speaking 
directly with prosecutors and probing them for how they may arrive at a decision to charge the true perpetrator with the wrongful conviction crime.

For a few reasons, our estimate of cases in which the statutes of limitations would prevent the charging of a true perpetrator are an underestimate. First, our coding for statutes of limitations was limited to the identified top charge, which was done purposely to provide a conservative estimate of the number of true perpetrators who would be protected from charges due to an expired statute of limitations. However, as we posited when discussing why it was still important to charge true perpetrators even if they are already incarcerated, bringing charges for all crimes committed serves to provide justice for the victims and punishment for the offenders. The same can be said for charging an individual for all of the crimes they committed during a single criminal event. By excluding the lesser crimes from our analysis and focusing on the ability to charge a true perpetrator instead of charging an individual crime, we likely severely underestimated how impactful statutes of limitations are on charging true perpetrators. Future research should look further into all crimes a true perpetrator could potentially be charged with and non-DNA based exonerations, thus estimating a more accurate judgment on the impact of these statutes. Additionally, we did not examine how DNA exceptions for statutes of limitations impacted the statutes of limitations faced by the true perpetrators in our sample. It is possible that there are statutes in our sample that were waived or extended, therefore eliminating cases in which the statute of limitations served as a prohibitive factor to the true perpetrator being charged for the wrongful conviction crime. Thus, future research should further examine how these statutes of limitations effect identifying and charging true perpetrators in wrongful convictions cases.

Another next step for researchers would be to include the perspective of the crime victims, and how their opinions about and willingness to participate in official action against the true perpetrator affects the odds of them being identified and charged. As previously discussed, prosecutors may be less willing to reinvestigate a wrongful conviction that was based on sexual assault or abuse for fear of upsetting or retraumatizing the victims. In fact, research has shown that the process of seeing their case reopened can be traumatizing for crime victims (Irazola et al., 2013) and impact their likelihood to support prosecution (Kingsnorth \& MacIntosh, 2004), especially for those who suffered great harm (Spohn and Holleran, 2001), such as sexual assault or abuse. This point is best illustrated by both Jennifer Thompson-Cannino and Tomeisha Artis, who were both victims of rape and whose mistaken eyewitness identifications contributed to wrongful convictions. As Jennifer Thompson-Cannino explained about discovering this fact, "Silently, I berated myself. It meant I had screwed up...I had brought disgrace upon [the detective's] investigation, and the whole Burlington Police Department" (Thompson-Cannino, Cotton, \& Torneo, 2009, p. 213). She continues, stating, “... [the detective] and [my husband] were both worried about the effects of me reliving it all..." (Thompson-Cannino, Cotton, \& Torneo, 2009, p. 236). Both women also experienced a fear of public backlash after the men they identified were exonerated and the true perpetrator found, with Tomeisha Artis stating, "It was horrible for me...The comments that people was saying, that I needed to go to prison. I picked this guy out. I needed to pay" ("National Institute of Justice," 2017), and Jennifer Thompson-Cannino claiming, "I had spent so many years protected by law from the public's knowing my name...The mistake I made affected so many lives...I knew it was risky to show my face on TV" (ThompsonCannino, Cotton, \& Torneo, 2009, pp. 236-237). 
Unfortunately, their fears are justified. Due to the fact that sexual assault is seen as qualitatively different from other crimes, the individuals accused and convicted of committing such offenses face serious consequences, both from a sentencing and societal perspective (Brody \& Acker, 2015). Being partially responsible for causing such stigma to attach to an innocent person due to a mistaken eyewitness identification may retraumatize victims in wrongful convictions cases even further and cause them to experience backlash from society. Therefore, the opinion of and impact on victims may have a strong impact on the prosecutor's discretion as related to identifying and charging of true perpetrators, especially in cases of sexual assault and sexual abuse, and thus deserves careful consideration in future research.

Although they are some of the first to examine true perpetrator identification and charging, the present studies have implications for criminal justice policy and practice. Practitioners, victims, exonerees, and the public alike have an interest in bringing these actual perpetrators to justice and should therefore focus on abolishing barriers that would inhibit such actions. This could take many forms, from making it common practice to charge those already in prison to lengthen their sentence and ensure public safety, to abolishing statutes of limitations that make it impossible to do so. By continuing to do research on these issues, the possibility of creating evidence-based policy increases, thus creating robust laws that are backed by science.

\section{References}

Acker, James R. (2013). The Flipside Injustice of Wrongful Convictions: When the Guilty Go Free. Albany Law Review, 76, 1629.

http://www.albanylawreview.org/Articles/Vol76_3/76.3.1629\%20Acker\%20(done).pdf.

Acker, James R., \& Redlich, Allison D. (2011). Wrongful conviction: Law, science, and policy. Carolina Academic Press.

Albonetti, Celesta A. (1987). Prosecutorial Discretion: The Effects of Uncertainty. Law and Society Review, 291-313.

https://www.jstor.org/stable/3053523.

Baumgartner, Frank R.; De Boef, Suzanna L., \& Boydstun, Amber E. (2008). The Decline Of The Death Penalty And The Discovery Of Innocence. Cambridge University Press.

Baumgartner, Frank R.; Grigg, Amanda; Ramirez, Rachelle, \& Lucy, J. Sawyer. (2018). The Mayhem of Wrongful Liberty: Documenting the Crimes of True Perpetrators in Cases of Wrongful Incarceration. Albany Law Review, 81(4), 1261.

http://www.albanylawreview.org/articles/vol81_4/1263\%20baumgartner\%20production. pdf.

Berger v. United States, 295 U.S. 78 (1935).

Bingham, Andrea; Cochran, John K.; Boots, Denise P., \& Heide, Kathleen M. (2013). Public Support for Preventive/Corrective Remedies Against Miscarriages of Justice in Capital Cases. Justice Quarterly, 30(4), 594-618. https://doi.org/10.1080/07418825.2011.619560. 
Blair, Irene V.; Judd, Charles M., \& Fallman, Jennifer L. (2004). The Automaticity of Race and Afrocentric Racial Features in Social Judgments. Journal of Personality and Social Psychology, 87(6), 763-778. https://doi.org/10.1037/0022-3514.87.6.763.

Bowers, Josh. (2010). Legal Guilt, Normative Innocence, And the Equitable Decision Not to Prosecute. Columbia Law Review, 1655. https://www.jstor.org/stable/27896309.

Bowman, Rachel, \& Gould, Jon B. (2020). Prosecutorial Involvement in Exoneration. The Wrongful Conviction Law Review, 1(1), 74.https://doi.org/10.29173/wclawr4.

Brady v. Maryland, 373 U.S. 83. (1963).

Brody, David C., \& Acker, James R. (2015). Rape and Sexual Assault. In Criminal Law (pp. 265295). Jones \& Bartlett Learning.

Burke, Alafair S. (2006). Neutralizing Cognitive Bias: An Invitation to Prosecutors. Journal of Law and Liberty, 2, 512-530.

https://scholarlycommons.law.hofstra.edu/cgi/viewcontent.cgi?referer=\&httpsredir=1\&ar ticle $=1744 \&$ context=faculty_scholarship.

Carmichael, Jason T., \& Kent, Stephanie L. (2015). The Use of Lethal Force by Canadian Police Officers: Assessing the Influence of Female Police Officers and Minority Threat Explanations on Police Shootings Across Large Cities. American Journal of Criminal Justice, 40(4), 703-721. https://doi.org/10.1007/s12103-014-9283-1.

Cho, Ji Young, \& Lee, Eun-Hee. (2014). Reducing Confusion About Grounded Theory and Qualitative Content Analysis: Similarities and Differences. The Qualitative Report, 19(32), 1-21. https://iribresearch.ir/rm/maghaleh/6.pdf.

Clark, Steven E. (2012). Costs and Benefits of Eyewitness Identification Reform: Psychological Science and Public Policy. Perspectives on Psychological Science, 7(3), 238-259. https://doi.org/10.1177/1745691612439584.

Clow, Kimberley A.; Blandisi, Isabella M.; Ricciardelli, Rose, \& Schuller, Regina A. (2011). Public Perception of Wrongful Conviction: Support for Compensation and Apologies. Albany Law Review, 75, 1415.

http://www.albanylawreview.org/Articles/Vol75_3/75.3.0007\%20Clow.pdf.

Conroy, John, \& Warden, Rob. (2011). Special Investigation: The High Costs of Wrongful Convictions. Better Government Association. https://www.bettergov.org/news/specialinvestigation-the-high-costs-of-wrongful-convictions/.

Convicting the Innocent. (2020). DNA Exonerations Database.

https://convictingtheinnocent.com/.

Cooper, Glinda S., \& Meterko, Vanessa. (2019). Cognitive Bias Research in Forensic Science: A Systematic Review. Forensic Science International, 297, 35-46.

https://doi.org/10.1016/j.forsciint.2019.01.016.

Davis, Angela J. (2009). Arbitrary Justice: The Power Of The American Prosecutor. Oxford University Press.

Demos, Moira, \& Ricciardi, Laura. (Executive Producers). (2015-2018). Making a Murderer [TV series]. Netflix. 
Devine, Patricia G. (1989). Stereotypes and Prejudice: Their Automatic and Controlled Components. Journal of Personality and Social Psychology, 56(1), 5-18. https://doi.org/10.1037/0022-3514.56.1.5.

DNA Clears Man in Rape, Judge Rules. (2006, November 1). New York Times. https://www.nytimes.com/2006/11/01/us/01rape.html.

Eberhardt, Jennifer L.; Davies, Paul G.; Purdie-Vaughns, Valerie J., \& Johnson, Sheri L. (2006). Looking Deathworthy: Perceived Stereo Typicality of Black Defendants Predicts CapitalSentencing Outcomes. Psychological Science, 17(5), 383-386. https://doi.org/10.1111/j.1467-9280.2006.01716.x.

Eisenstein, James, \& Jacob, Herbert. (1977). Felony Justice: An Organizational Analysis Of Criminal Courts. Little, Brown, and Co.

Emch, Dale. (2001, April 13). Toledo Man Linked to the 1981 Murder for Which Brown Was Convicted. The Blade. https://www.toledoblade.com/local/police-fire/2001/04/13/Toledoman-linked-to-the-1981-murder-for-which-Brown-was-convicted/stories/200104130012.

End the Backlog. (n.d.). Statute of Limitations. http://www.endthebacklog.org/informationsurvivors-survivors-rights-locating-rape-kit/statute-limitations.

Fan, David P.; Keltner, Kathy. A., \& Wyatt, Robert O. (2002). A Matter of Guilt or Innocence: How News Reports Affect Support for The Death Penalty in The United States. International Journal of Public Opinion Research, 14, 439-452.

https://doi.org/10.1093/ijpor/14.4.439.

Findley, Keith A. (2008). Innocents at Risk: Adversary Imbalance, Forensic Science, And the Search for Truth. Seton Hall Law Review, 38, 893. https://ssrn.com/abstract=1144886.

Findley, Keith A., \& Scott, Michael S. (2006). The Multiple Dimensions of Tunnel Vision in Criminal Cases. Wisconsin Law Review, 291. https://ssrn.com/abstract=911240.

Forejustice. (2018). Innocents Database. http://forejustice.org/search_idb.htm.

Ga. Code $§ 17-3-2.1$

Garrett, Brandon L. (2011). Convicting the Innocent. Harvard University Press.

Garrett, Brandon L., \& Neufeld, Peter J. (2009). Invalid Forensic Science Testimony and Wrongful Convictions. Virginia Law Review, 1. https://ssrn.com/abstract=1354604.

Gershman, Bennett L. (2010). Prosecutorial Decision Making and Discretion in The Charging Function. Hastings LJ, 62, 1259. http://digitalcommons.pace.edu/lawfaculty/797/.

Ginsburg, Douglas H., \& Hunt, Hyland. (2009). The Prosecutor and Post-Conviction Claims of Innocence: DNA And Beyond. Ohio State Journal of Criminal Law, 7, 771. https://kb.osu.edu/bitstream/handle/1811/73167/OSJCL_V7N2_771.pdf.

Goff, Phillip A.; Jackson, Matthew C.; Leone, Brooke A. L.; Culotta, Carmen M., \& DiTomasso, Natalie A. (2014). The Essence of Innocence: Consequences of Dehumanizing Black Children. Journal of Personality and Social Psychology, 526-545. https://doi.org/10.1037/a0035663. 
Goldberg, Judith, \& Siegel, David M. (2002). The Ethical Obligations of Prosecutors in Cases Involving Postconviction Claims of Innocence. California Western Law Review, 38(2), 389. https://ssrn.com/abstract=2593804.

Goldstein, Abraham S. (1981). The Passive Judiciary: Prosecutorial Discretion and The Guilty Plea. Louisiana State University Press.

Gordon, Neil. (2003, June 26). Actual Innocence. The Center for Public Integrity. https://www.publicintegrity.org/2003/06/26/5531/actual-innocence.

Gould, Jon B.; Carrano, Julia; Leo, Richard A., \& Young, Joseph. (2013). Predicting Erroneous Convictions: A Social Science Approach to Miscarriages of Justice. University of San Francisco Law Research Paper No. 2013-20.

https://www.ncjrs.gov/pdffiles 1/nij/grants/241389.pdf.

Gould, Jon B., \& Leo, Richard A. (2010). One Hundred Years Later: Wrongful Convictions After A Century of Research. The Journal of Criminal Law and Criminology, 825-868. https://scholarlycommons.law.northwestern.edu/jclc/vol100/iss3/7.

Gould, Jon B., \& Leo, Richard A. (2015). The Path To Exoneration. Albany Law Review, 79(2), 325.

http://www.albanylawreview.org/Articles/vol79_2/325\%20Gould_Leo\%20FINAL\%20M IX 79.2.pdf.

Green, Bruce A. (2019). Prosecutors in The Court of Public Opinion. Duquesne Law Review, 57(2), 271. https://ssrn.com/abstract=3399082.

Green, Bruce A., \& Yaroshefsky, Ellen. (2009). Prosecutorial Discretion and Post-Conviction Evidence of Innocence. Ohio State Journal of Criminal Law, 6(2), 467. http://hdl.handle.net/1811/73075.

Green, Frank. (2009, May 10). Citing DNA Test, Prisoner Asks Va. High Court to Clear Him In 1984 Rape. Richmond Times Dispatch. https://www.richmond.com/news/citing-dna-testprisoner-asks-va-high-court-to-clear-him-in-1984-rape/article_0ff53a06-60b3-53dda676-67f8b1a48f3b.html.

Green, Frank, \& Williams, Reed. (2009, March 19). DNA Evidence Casts Doubt On 1984 Rape Conviction. Richmond Times Dispatch. https://www.richmond.com/news/dna-evidencecasts-doubt-on-1984-rape-conviction/article_90f6e627-ab99-5feb-a2e14be6fe837e8a.html.

Greenawalt, R. Kent. (1987). Conflicts Of Law And Morality. Oxford University Press.

Greene, Susan. (2007). Evidence Proves Innocence After 24 Years. The Denver Post. https://www.denverpost.com/2007/07/24/evidence-proves-innocence-after-24-years/\#.

Gross, Samuel R., \& Shaffer, Michael. (2012). Exonerations in The United States, 1989-2012: Report by The National Registry of Exonerations. University of Michigan Law School, 72, 610-632.

https://www.law.umich.edu/special/exoneration/Documents/exonerations_us_1989_2012 full report.pdf. 
Innocence Project (2020). DNA Exonerations In The United States.

https://www.innocenceproject.org/dna-exonerations-in-the-united-states/.

Irazola, Seri; Williamson, Erin; Stricker, Julie, \& Niedzwiecki, Emily. (2013). Study of Victim Experiences of Wrongful Conviction. U.S. Department of Justice. https://www.ncjrs.gov/pdffiles1/nij/grants/244084.pdf.

Jacoby, Joan E. (1980) The American Prosecutor: A Search For Identity. Lexington.

Jonakait, Randolph N. (1987). Ethical Prosecutor's Misconduct. Criminal Law Bulletin, 23(6), 550-567. https://www.ncjrs.gov/App/Publications/abstract.aspx?ID=108090.

Kassin, Saul M.; Dror, Itiel E., \& Kukucka, Jeff. (2013). The Forensic Confirmation Bias: Problems, Perspectives, And Proposed Solutions. Journal of Applied Research in Memory and Cognition, 2(1), 42-52.https://doi.org/10.1016/j.jarmac.2013.01.001.

Kingsnorth, Rodney F., \& Macintosh, Randall C. (2004). Domestic Violence: Predictors of Victim Support for Official Action. Justice Quarterly, 21(2), 301-328.

https://doi.org/10.1080/07418820400095821.

Kreimer, Seth F., \& Rudovsky, David. (2002). Double Helix, Double Bind: Factual Innocence and Postconviction DNA Testing. University of Pennsylvania Law Review, 151(2), 547. https://scholarship.law.upenn.edu/faculty_scholarship/1168.

Leo, Richard A. (2017). The Criminology of Wrongful Conviction: A Decade Later. Journal of Contemporary Criminal Justice, 33(1), 82-106.

https://doi.org/10.1177/1043986216673013.

Levenson, Laurie L. (2016). The Problem with Cynical Prosecutor's Syndrome: Rethinking A Prosecutor's Role in Post-Conviction Cases. Berkeley Journal of Criminal Law, 20, 335. http://dx.doi.org/10.15779/Z38056D.

Leveritt, Mara. (2002). Devil's knot: The True Story Of The West Memphis Three. Atria Books.

Lord, Charles G.; Ross, Lee, \& Lepper, Mark R. (1979). Biased Assimilation and Attitude Polarization: The Effects of Prior Theories on Subsequently Considered Evidence. Journal of Personality and Social Psychology, 37(11), 2098-2109. https://doi.org/10.1037/00223514.37.11.2098.

Medwed, Daniel S. (2004). The Zeal Deal: Prosecutorial Resistance to Post-Conviction Claims of Innocence. Boston University Law Review, 84, 125. https://ssrn.com/abstract=833624.

Medwed, Daniel S. (2008). Innocentrism. University of Illinois Law Review, 1549. https://ssrn.com/abstract=1006238.

Meterko, Vanessa. (2016). Strengths And Limitations Of Forensic Science: What DNA Exonerations Have Taught Us And Where To Go From Here. West Virginia Law Review, 119(2), 8. https://researchrepository.wvu.edu/wvlr/vol119/iss2/8.

Miller, Frank W., \& Remington, Frank J. (1969). Prosecution: The Decision To Charge A Suspect With A Crime. Little, Brown.

Moretti, Francesca; van Vliet, Liesbeth; Bensing, Jozien; Deledda, Giuseppe; Mazzi, Mariangela; Rimondini, Michela; Zimmermann, Christa, \& Fletcher, Ian (2011). A Standardized 
Approach to Qualitative Content Analysis of Focus Group Discussions from Different Countries. Patient Education and Counseling, 82(3), 420-428.

https://doi.org/10.1016/j.pec.2011.01.005.

N.J. Stat. § 2C:1-6.

N.Y. CPL $§ 440.10$ Motion to vacate judgment.

https://www.nysenate.gov/legislation/laws/CPL/440.10.

Napue v. Illinois, 360 U.S. 264 (1959).

National Institute of Justice. (2017, October 1). Just Wrong: The Aftermath Of Wrongful Convictions [Video]. YouTube.

https://www.youtube.com/watch?v=jF52Pp2Knr4\&feature=emb_title.

Norris, Robert J. (2014). Exoneree Compensation: Current Policies and Future Outlook. In M. Zalman \& J. Carrano (Eds.), Wrongful conviction and criminal justice reform: Making justice. Routledge.

Norris, Robert J., \& Mullinix, Kevin J. (2019). Framing Innocence: An Experimental Test of The Effects of Wrongful Convictions on Public Opinion. Journal of Experimental Criminology, 1-24. https://doi.org/10.1007/s11292-019-09360-7.

Norris, Robert J.; Bonventre, Catherine L., \& Acker, James R. (2018). When Justice Fails: Causes And Consequences Of Wrongful Convictions. Carolina Academic Press.

Norris, Robert J.; Weintraub, Jennifer N.; Acker, James R.; Redlich, Allison D., \& Bonventre, Catherine L. (2019). The Criminal Costs of Wrongful Convictions: Can We Reduce Crime by Protecting the Innocent? Criminology and Public Policy. 1-22.

https://doi.org/10.1111/1745-9133.12463.

O'Brien, Barbara. (2009). A Recipe for Bias: An Empirical Look at The Interplay Between Institutional Incentives and Bounded Rationality in Prosecutorial Decision Making. Missouri Law Review, 74(4), 999. https://ssrn.com/abstract=1410118.

Ohio Rev. Code Ann. § 2901.13.

Orenstein, Aviva. (2011). Facing the Unfaceable: Dealing with Prosecutorial Denial in Postconviction Cases of Actual Innocence. San Diego Law Review, 48, 401. https://ssrn.com/abstract=1682076.

Packer, Herbert L. (1968). The Limits Of The Criminal Sanction. Stanford University Press.

Penzell, Abigail. (2007). Apology in The Context of Wrongful Conviction: Why the System Should Say It's Sorry. Cardozo Journal of Conflict Resolution, 9, 145.

https://cardozojcr.com/vol9no1/145-162.pdf.

Platz, Stephanie J., \& Hosch, Harmon M. (1988). Cross-Racial/Ethnic Eyewitness Identification: A Field Study. Journal of Applied Social Psychology, 18(11), 972-984. https://doi.org/10.1111/j.1559-1816.1988.tb01187.x.

Rape, Abuse \& Incest National Network. (2012). Statute of Limitations Summary. https://www.rainn.org/pdf-files-and-other-documents/Public-Policy/Legalresources/2012/Statute\%20of\%20Limitations\%20Summary.pdf. 
Schoenfeld, Heather. (2005). Violated Trust: Conceptualizing Prosecutorial Misconduct. Journal of Contemporary Criminal Justice, 21(3), 250-271. https://doi.org/10.1177/1043986205278722.

Smith, Robert J., \& Levinson, Justin D. (2012). The Impact Of Implicit Racial Bias On The Exercise Of Prosecutorial Discretion, Seattle University Law Review, 35, 795. https://ssrn.com/abstract=2045316.

Spohn, Cassia, \& Holleran, David. (2001). Prosecuting Sexual Assault: A Comparison of Charging Decisions in Sexual Assault Cases Involving Strangers, Acquaintances, And Intimate Partners. Justice Quarterly, 18(3), 651-688. https://doi.org/10.1080/07418820100095051.

Stratton Greg. (2019) Wrongful Conviction, Pop Culture, And Achieving Justice in The Digital Age. In D. Akrivos. \& A. Antoniou (Eds.), Crime, Deviance and Popular Culture (pp. 177201). Palgrave Macmillan. https://doi.org/10.1007/978-3-030-04912-6_8.

Teitelbaum, Stephanie, \& Geiselman, R. Edward. (1997). Observer Mood and Cross-Racial Recognition of Faces. Journal of Cross-Cultural Psychology, 28(1), 93-106. https://doi.org/10.1177/0022022197281006.

The Center for Public Integrity. (2003, June 26). Misconduct and Punishment. https://publicintegrity.org/2003/06/26/5532/misconduct-and-punishment.

The National Registry of Exonerations (2019). Exonerations in 2018. http://www.law.umich.edu/special/exoneration/Documents/Exonerations\%20in\%202018. pdf.

The National Registry of Exonerations (n.d.-a). https://www.law.umich.edu/special/exoneration/Pages/about.aspx.

The National Registry of Exonerations (n.d.-b). Glossary. https://www.law.umich.edu/special/exoneration/Pages/glossary.aspx.

Thompson-Cannino, Jennifer; Cotton, Ronald, \& Torneo, Erin. (2009). Picking Cotton: Our Memoir Of Injustice And Redemption. Macmillan.

Thompson, Adina M.; Molina, Oscar R., \& Levett, Lora M. (2011). After Exoneration: An Investigation of Stigma and Wrongfully Convicted Persons. Albany Law Review, 75, 1373. http://www.albanylawreview.org/Articles/Vol75 3/75.3.0006\%20Thompson.pdf.

U.S. Dept. of Justice, Criminal Resource Manual 649 (2020), https://www.justice.gov/archives/jm/criminal-resource-manual-649-statute-limitationsdefenses.

United States v. Lovasco, 431 U.S. 783, 789 (1977).

Unnever, James D., \& Cullen, Francis T. (2005). Executing the Innocent and Support for Capital Punishment: Implications for Public Policy. Criminology \& Public Policy, 4(1), 3-38. https://doi.org/10.1111/j.1745-9133.2005.00002.x.

Viglione, Jill; Hannon, Lance, \& DeFina, Robert. (2011). The Impact of Light Skin on Prison Time for Black Female Offenders. The Social Science Journal, 48(1), 250-258. https://doi.org/10.1016/j.soscij.2010.08.003. 
Warden, Rob. (2015, December 9). Despite DNA, Alvarez Fails to Bring Charges in Two Murders. InjusticeWatch.https://www.injusticewatch.org/commentary/2015/anita-alvarez-giveskillers-passes/.

Wayte v. United States, 470 US 598 (1985)

Webster, Elizabeth. (2019). A Postconviction Mentality: Prosecutorial Assistance in Exoneration Cases. Justice Quarterly, 36(2), 323-349.

https://doi.org/10.1080/07418825.2017.1399212.

Weintraub, Jennifer N. (2020). Obstructing Justice: The Association Between Prosecutorial Misconduct and The Identification of True Perpetrators. Crime \& Delinquency. 1-22. https://doi.org/10.1177/0011128719901107.

West, Emily M. (2010). Court Findings Of Prosecutorial Misconduct Claims In Postconviction Appeals And Civil Suits Among The First 255 DNA Exoneration Cases. Innocence Project. https://www.innocenceproject.org/wpcontent/uploads/2016/04/pmc_appeals_255_final_oct_2011.pdf.

West, Emily M., \& Meterko, Vanessa. (2015). Innocence Project: DNA Exonerations, 1989-2014: Review Of Data And Findings From The First 25 Years. Albany Law Review, 79, 717. https://ssrn.com/abstract=2986970.

Westervelt, Saundra D., \& Cook, Kimberly J. (2008). Coping With Innocence After Death Row. Contexts, 7(4), 32-37.https://doi.org/10.1525/ctx.2008.7.4.32.

Westervelt, Saundra D., \& Cook, Kimberly J. (2012). Life After Death Row: Exonerees' Search For Community And Identity. Rutgers University Press.

Yaksic, Enzo; Bulut Allred, Tara; Drakulic, Christa; Mooney, Robyn; De Silva, Raneesha; Geyer, Penny; Wills, Angelica; Comerford, Caroline, \& Ranger, Rebekah. (2020). How Much Damage Do Serial Homicide Offenders Wrought While the Innocent Rot in Prison? A tabulation of preventable deaths as outcomes of sentinel events. Psychology, Crime \& Law, 1-13. https://doi.org/10.1080/1068316X.2020.1774590.

Yaroshefsky, Ellen. (2013). Why Do Brady Violations Happen? Cognitive Bias And Beyond. Maurice A. Deane School of Law at Hofstra University. https://scholarlycommons.law.hofstra.edu/faculty_scholarship/1025.

Zacharias, Fred C. (2005). The Role of Prosecutors in Serving Justice After Convictions. Vanderbilt Law Review, 58(1), 171. https://ssrn.com/abstract=803044.

Zalman, Marvin; Larson, Matthew J., \& Smith, Brad. (2012). Citizens' Attitudes Toward Wrongful Convictions. Criminal Justice Review, 37(1), 51-69. https://doi.org/10.1177/0734016811428374. 


\section{Appendix}

Exonerees and True Perpetrators by Criminal Event

\begin{tabular}{|c|c|}
\hline Exoneree(s) & True Perpetrator(s) \\
\hline Abbitt, Joseph Lamont & Unknown $^{\mathrm{a}}$ \\
\hline Abdal, Warith Habib & Unknown $^{\mathrm{a}}$ \\
\hline Abernathy, Christopher & Unknown $^{\mathrm{a}}$ \\
\hline $\begin{array}{l}\text { Adams, Kenneth } \\
\text { Gray, Paula } \\
\text { Jimerson, Verneal } \\
\text { Rainge, Willie } \\
\text { Williams, Dennis }\end{array}$ & $\begin{array}{l}\text { Johnson, Ira } \\
\text { Robinson, Arthur } \\
\text { Rodriguez, Juan }\end{array}$ \\
\hline Alejandro, Gilbert & Unknown $^{\mathrm{a}}$ \\
\hline Alexander, Richard & Murphy, Michael \\
\hline Allen, Donovan & Unknown $^{\mathrm{a}}$ \\
\hline Anderson, Marvin & Lincoln, John \\
\hline Arledge, Randolph & Sims, David \\
\hline Atkins, Herman & Unknown $^{\mathrm{a}}$ \\
\hline Avery, Steven & Allen, Gregory \\
\hline Avery, William & Ellis, Walter ${ }^{b}$ \\
\hline Ayers, David & Unknown $^{\mathrm{a}}$ \\
\hline Bain, James & Unknown $^{\mathrm{a}}$ \\
\hline Barbour, Bennett & Glass Jr., James Moses \\
\hline Barnes, Steven & Unknown $^{\mathrm{a}}$ \\
\hline Barnhouse, William & Unknown $^{\mathrm{a}}$ \\
\hline $\begin{array}{l}\text { Barr, Jonathan } \\
\text { Harden, James } \\
\text { Sharp, Shainne } \\
\text { Taylor, Robert } \\
\text { Veal, Robert }\end{array}$ & Randolph, Willie B. \\
\hline
\end{tabular}




\begin{tabular}{|c|c|}
\hline Bauer, Chester & Unknown $^{\mathrm{a}}$ \\
\hline Beaver, Antonio & Unnamed $^{\mathrm{c}}$ \\
\hline Beranek, Richard & Unknown $^{\mathrm{a}}$ \\
\hline Bibbins, Gene & Gordon, Emanuel \\
\hline $\begin{array}{l}\text { Bivens, Phillip } \\
\text { Dixon, Bobby Ray } \\
\text { Ruffin, Larry }\end{array}$ & Harris, Andrew \\
\hline Blair, Michael & Unknown $^{\mathrm{a}}$ \\
\hline Bledsoe, Floyd & Bledsoe, Tom \\
\hline Bloodsworth, Kirk & Rufner, Kimberly S. \\
\hline Booker, Donte & Adams, Pettis \\
\hline Boquete, Orlando & Unknown $^{\mathrm{a}}$ \\
\hline $\begin{array}{l}\text { Bradford, Marcellius } \\
\text { Ollins, Calvin } \\
\text { Ollins, Larry } \\
\text { Saunders, Omar }\end{array}$ & $\begin{array}{l}\text { Harris, Eddie "Bo" } \\
\text { Roach, Duane }\end{array}$ \\
\hline Bradford, Ted & Unnamed $^{\mathrm{c}}$ \\
\hline Bravo, Mark & Unknown $^{\mathrm{a}}$ \\
\hline Brewer, Kennedy & Johnson, Justin \\
\hline Briscoe, Johnny & Smith, Larry \\
\hline Brison, Dale & Unknown $^{\mathrm{a}}$ \\
\hline Bromgard, Jimmy Ray & Tipton, Ronald Dwight \\
\hline Brown, Danny & Preston, Sherman \\
\hline Brown, Dennis & Unknown $^{\mathrm{a}}$ \\
\hline Brown, Jr., Knolly & Unknown $^{\mathrm{a}}$ \\
\hline Brown, Keith & Mosley, Samuel \\
\hline $\begin{array}{l}\text { Brown, Leon } \\
\text { McCollum, Henry }\end{array}$ & Artis, Roscoe \\
\hline
\end{tabular}




\begin{tabular}{|c|c|}
\hline Brown, Nathan & Unnamed $^{\mathrm{c}}$ \\
\hline Brown, Patrick & Rickard, Robert \\
\hline Brown, Roy & Bench, Barry \\
\hline Bryant, Malcolm & Unknown $^{\mathrm{a}}$ \\
\hline Bryson, David & Unknown $^{\mathrm{a}}$ \\
\hline Bullock, Ronnie & Unknown $^{\mathrm{a}}$ \\
\hline Buntin, Harold & Unknown $^{\mathrm{a}}$ \\
\hline Burnette, Victor & Unknown $^{\mathrm{a}}$ \\
\hline Butler, Jr., A.B. & Unknown $^{\mathrm{a}}$ \\
\hline Byrd, Kevin & Unknown $^{\mathrm{a}}$ \\
\hline Cage, Dean & Unknown $^{\mathrm{a}}$ \\
\hline Callace, Leonard & Unknown $^{\mathrm{a}}$ \\
\hline Cameron, Ronjon & Unknown $^{\mathrm{a}}$ \\
\hline Camm, David & Charles Boney \\
\hline Capozzi, Anthony & Sanchez, Altemio C. \\
\hline Caravella, Anthony & Unknown $^{\mathrm{a}}$ \\
\hline Chalmers, Terry & Unknown $^{\mathrm{a}}$ \\
\hline Chaparro, Anthony & Unknown $^{\mathrm{a}}$ \\
\hline Charles, Clyde & Charles, Milo \\
\hline Charles, Ulysses Rodriguez & Unknown $^{\mathrm{a}}$ \\
\hline Chatman, Charles & Unknown $^{\mathrm{a}}$ \\
\hline Clark, Robert & Arnold, F. Anthony \\
\hline Coco, Allen & Unknown $^{\mathrm{a}}$ \\
\hline Cole, Timothy B. & Johnson, Jerry Wayne \\
\hline $\begin{array}{l}\text { Coleman, Nevest } \\
\text { Fulton, Darryl }\end{array}$ & Unnamed $^{\mathrm{c}}$ \\
\hline
\end{tabular}




\begin{tabular}{|c|c|}
\hline Cotton, Ronald & Poole, Bobby \\
\hline Courtney, Sedrick & Unknown $^{\mathrm{a}}$ \\
\hline Courtney, Uriah & Unnamed $^{\mathrm{c}}$ \\
\hline Cowans, Stephan & Unknown $^{\mathrm{a}}$ \\
\hline Criner, Roy & Unknown $^{\mathrm{a}}$ \\
\hline Cromedy, McKinley & Unknown $^{\mathrm{a}}$ \\
\hline Crotzer, Alan & Unknown $^{\mathrm{a}}$ \\
\hline $\begin{array}{l}\text { Cruz, Rolando } \\
\text { Hernandez, Alejandro }\end{array}$ & Dugan, Brian \\
\hline Cunningham, Calvin Wayne & Unknown $^{\mathrm{a}}$ \\
\hline Dabbs, Charles & Unknown $^{\mathrm{a}}$ \\
\hline Dail, Dwayne Allen & Neal, William Jackson \\
\hline $\begin{array}{l}\text { Danziger, Richard } \\
\text { Ochoa, Christopher }\end{array}$ & Marino, Achim Josef \\
\hline Davidson, Willie & Unknown $^{\mathrm{a}}$ \\
\hline Davis, Cody & Prichard, Jeremy \\
\hline $\begin{array}{l}\text { Davis, Dewey } \\
\text { Davis, Gerald }\end{array}$ & Unknown $^{\mathrm{a}}$ \\
\hline Davis, Donya & Unknown $^{\mathrm{a}}$ \\
\hline Davis, Jeramie & Davila, Julio \\
\hline $\begin{array}{l}\text { Davis, Larry } \\
\text { Northrop, Alan }\end{array}$ & Unknown $^{\mathrm{a}}$ \\
\hline Daye, Frederick Renee & $\begin{array}{l}\text { Pringle, David } \\
\text { Smallwood, Eddie }\end{array}$ \\
\hline $\begin{array}{l}\text { Dean, James } \\
\text { Gonzalez, Kathleen } \\
\text { Shelden, Debra } \\
\text { Taylor, Ada JoAnn } \\
\text { White, Joseph } \\
\text { Winslow, Thomasb }\end{array}$ & Smith, Bruce \\
\hline
\end{tabular}




\begin{tabular}{|c|c|}
\hline Dedge, Wilton & Unknown $^{\mathrm{a}}$ \\
\hline Deskovic, Jeffrey & Cunningham, Steven \\
\hline Dewey, Robert & Thames, Douglas \\
\hline Diamond, Garry & Unknown $^{\mathrm{a}}$ \\
\hline Diaz, Luis & Unknown $^{\mathrm{a}}$ \\
\hline Dillon, William & Unknown $^{\mathrm{a}}$ \\
\hline Dixon, John & Unknown $^{\mathrm{a}}$ \\
\hline Dominguez, Alejandro & Unknown $^{\mathrm{a}}$ \\
\hline Doswell, Thomas & Unknown $^{\mathrm{a}}$ \\
\hline Dotson, Gary & Unknown $^{\mathrm{a}}$ \\
\hline $\begin{array}{l}\text { Dupree, Jr., Cornelius } \\
\text { Massingill, Anthony }\end{array}$ & Unknown $^{\mathrm{a}}$ \\
\hline Durham, Timothy & Unknown $^{\mathrm{a}}$ \\
\hline $\begin{array}{l}\text { Echols, Douglas } \\
\text { Scott, Samuel }\end{array}$ & Unknown $^{\mathrm{a}}$ \\
\hline Elkins, Clarence & Mann, Earl \\
\hline Erby, Lonnie & Moore, Johnnie \\
\hline Evans, Jerry Lee & Unknown $^{\mathrm{a}}$ \\
\hline $\begin{array}{l}\text { Evans, Michael } \\
\text { Terry, Paul }\end{array}$ & Unknown $^{\mathrm{a}}$ \\
\hline Fain, Charles & Unknown $^{\mathrm{a}}$ \\
\hline Fappiano, Scott & Unknown $^{\mathrm{a}}$ \\
\hline Fears, Jr., Joseph R. & Knighton \\
\hline Fogle, Lewis & Unknown $^{\mathrm{a}}$ \\
\hline Fountain, Wiley & Unknown $^{\mathrm{a}}$ \\
\hline Frey, Joseph & Crawford, James E. \\
\hline Fritz, Dennis & Gore, Glenn \\
\hline
\end{tabular}




\begin{tabular}{|c|c|}
\hline \multicolumn{2}{|l|}{ Williamson, Ronald Keith } \\
\hline Fuller, Larry & Unknown $^{\mathrm{a}}$ \\
\hline Gagnon, Richard & Hill, Bruce Antwain \\
\hline Gates, Donald Eugene & Unknown $^{\mathrm{a}}$ \\
\hline Giles, James Curtis & $\begin{array}{l}\text { Brown, Michael } \\
\text { Bryant, Stanley }\end{array}$ \\
\hline Gillard, Larry & Unnamed $^{\mathrm{c}}$ \\
\hline Godschalk, Bruce & Unknown $^{\mathrm{a}}$ \\
\hline Gonzales-Barboza, Juan Carlos & Unknown $^{\mathrm{a}}$ \\
\hline Gonzalez, Angel & Unknown $^{\mathrm{a}}$ \\
\hline Gonzalez, Hector & Unknown $^{\mathrm{a}}$ \\
\hline Good, Donald Wayne & Unknown $^{\mathrm{a}}$ \\
\hline Goodman, Bruce Dallas & Unknown $^{\mathrm{a}}$ \\
\hline Gossett, Andrew & Unknown $^{\mathrm{a}}$ \\
\hline Gray, Anthony & Fleming, Anthony Gerald \\
\hline Gray, David A. & Unknown $^{\mathrm{a}}$ \\
\hline Green, Anthony Michael & Rhines, Rodney \\
\hline Green, Edward & Unknown $^{\mathrm{a}}$ \\
\hline Green, Kevin Lee & Parker, Gerald \\
\hline Green, Michael Anthony & Three Unnamed ${ }^{c}$ \\
\hline Gregory, William & Unknown $^{\mathrm{a}}$ \\
\hline $\begin{array}{l}\text { Hadaway, Sammy } \\
\text { Ott, Chaunte }\end{array}$ & Ellis, Walter ${ }^{\mathrm{b}}$ \\
\hline Halsey, Byron & Hall, Clifton \\
\hline $\begin{array}{l}\text { Halstead, Dennis } \\
\text { Kogut, John } \\
\text { Restivo, John }\end{array}$ & Unknown $^{\mathrm{a}}$ \\
\hline
\end{tabular}




\begin{tabular}{|c|c|}
\hline Harrell, Dion & Unknown $^{\mathrm{a}}$ \\
\hline Harris, William & Unknown $^{\mathrm{a}}$ \\
\hline Harrison, Clarence & Unknown $^{\mathrm{a}}$ \\
\hline Harward, Keith & Crotty, Jerry L. \\
\hline Hatchett, Nathaniel & Unknown $^{\mathrm{a}}$ \\
\hline $\begin{array}{l}\text { Hayes, Travis } \\
\text { Matthews, Ryan }\end{array}$ & Love, Rondell \\
\hline Haynesworth, Thomas & Davis Jr., Leon W. \\
\hline Heins, Chad & Unknown $^{\mathrm{a}}$ \\
\hline Henton, Eugene & Unknown $^{\mathrm{a}}$ \\
\hline Hicks, Anthony & Unknown $^{\mathrm{a}}$ \\
\hline Holdren, Larry & Unknown $^{\mathrm{a}}$ \\
\hline Holemon, Jeffrey & Unknown $^{\mathrm{a}}$ \\
\hline Holland, Dana & Bolden, Gordon \\
\hline Holloway, Daryl & Unknown $^{\mathrm{a}}$ \\
\hline Honaker, Edward & Unknown $^{\mathrm{a}}$ \\
\hline Howard, Darryl & Jones, Jermeck \\
\hline Hunt, Darryl & Brown, Willie E. \\
\hline Ireland, Kenneth & Benefield, Kevin M. \\
\hline $\begin{array}{l}\text { Isbell, Teddy } \\
\text { Kagonyera, Kenneth } \\
\text { Mills, Damian } \\
\text { Wilcoxson, Robert } \\
\text { Williams, Jr., Larry }\end{array}$ & $\begin{array}{l}\text { Pickens, Lacy } \\
\text { Rutherford, Robert } \\
\text { Summey, Bradford }\end{array}$ \\
\hline Jackson, Dwayne & Grissom, Howard Dupree \\
\hline $\begin{array}{l}\text { Jackson, Raymond } \\
\text { Williams, James }\end{array}$ & $\begin{array}{l}\text { Anderson, Frederick } \\
\text { Sayles, Marion Doll }\end{array}$ \\
\hline Jackson, Willie & Jackson, Milton \\
\hline
\end{tabular}




\begin{tabular}{|c|c|}
\hline James, Henry & Unknown $^{\mathrm{a}}$ \\
\hline Jean, Lesly & Unknown ${ }^{\mathrm{a}}$ \\
\hline Jenkins, Jerry Lee & Derr, Norman Bruce \\
\hline $\begin{array}{l}\text { Jenkins, Paul } \\
\text { Lawrence, Freddie Joe }\end{array}$ & David Wayne Nelson \\
\hline Johnson, Albert K. & Unnamed $^{c}$ \\
\hline Johnson, Andrew & Unknown $^{\mathrm{a}}$ \\
\hline Johnson, Anthony & Brown, Matthew \\
\hline Johnson, Arthur & Unnamed $^{c}$ \\
\hline Johnson, Calvin & Unknown $^{\mathrm{a}}$ \\
\hline Johnson, Larry & Unknown $^{\mathrm{a}}$ \\
\hline Johnson, Richard & Unknown $^{\mathrm{a}}$ \\
\hline Johnson, Rickey & McNeal, John C. \\
\hline Jones, Clifford & Unknown $^{\mathrm{a}}$ \\
\hline Jones, Joe C. & Russell, Joel L. \\
\hline Jones, Ronald & Unknown $^{\mathrm{a}}$ \\
\hline Karage, Entre Nax & Jordan, Keith \\
\hline $\begin{array}{l}\text { Kelley, Eric } \\
\text { Lee, Ralph }\end{array}$ & Dixon, Eric Anthony \\
\hline Kelly, Jr., William M. & Miller, Joseph \\
\hline Kordonowy, Paul D. & Unknown $^{\mathrm{a}}$ \\
\hline Kotler, Kerry & Unknown $^{\mathrm{a}}$ \\
\hline Krone, Ray & Phillips, Kenneth \\
\hline Laughman, Barry & Unknown $^{\mathrm{a}}$ \\
\hline Lavernia, Carlos Marcos & Unknown $^{\mathrm{a}}$ \\
\hline Lindsey, Johnnie & Unknown ${ }^{\mathrm{a}}$ \\
\hline
\end{tabular}




\begin{tabular}{|c|c|}
\hline Linscott, Steven & Unknown $^{\mathrm{a}}$ \\
\hline Lloyd, Eddie Joe & Unknown $^{\mathrm{a}}$ \\
\hline Lowery, Eddie & Brewer, Daniel Lee \\
\hline Lyons, Marcus & Anderson, Carl B. \\
\hline $\begin{array}{l}\text { Mahan, Dale } \\
\text { Mahan, Ronnie }\end{array}$ & Unknown $^{\mathrm{a}}$ \\
\hline Maher, Dennis & Unknown $^{\mathrm{a}}$ \\
\hline Marshall, Michael & Unnamed $^{\mathrm{c}}$ \\
\hline Mayes, Larry & Unknown $^{\mathrm{a}}$ \\
\hline McCarty, Curtis & Unknown $^{\mathrm{a}}$ \\
\hline McClendon, Robert & Unknown $^{\mathrm{a}}$ \\
\hline $\begin{array}{l}\text { McCray, Antron } \\
\text { Richardson, Kevin } \\
\text { Salaam, Yusef } \\
\text { Santana, Raymond } \\
\text { Wise, Korey }\end{array}$ & Reyes, Matias \\
\hline McGee, Arvin & Alberty, Edward \\
\hline McInnis, Edward & Unknown $^{\mathrm{a}}$ \\
\hline McKinney, Lawrence & Unknown $^{\mathrm{a}}$ \\
\hline McMillan, Clark Jerome & Boyd, David Louis \\
\hline Mercer, Michael & Brown, Arthur \\
\hline Miller, Billy Wayne & Unknown $^{\mathrm{a}}$ \\
\hline Miller, Christopher & $\begin{array}{l}\text { Boyd, Charles } \\
\text { Stadmire, Richard }\end{array}$ \\
\hline Miller, Jr., Robert Lee & Lott, Ronald \\
\hline Miller, Neil & Taylor, Lawrence \\
\hline Mitchell, Marvin & Unknown $^{\mathrm{a}}$ \\
\hline Mitchell, Perry & Unknown $^{\mathrm{a}}$ \\
\hline
\end{tabular}




\begin{tabular}{|c|c|}
\hline Moon, Brandon & Unknown $^{\mathrm{a}}$ \\
\hline Morton, Michael & Norwood, Mark Alan \\
\hline Moto, Vincent & Unknown $^{\mathrm{a}}$ \\
\hline Mumphrey, Arthur & $\begin{array}{l}\text { Mumphrey, Charles } \\
\text { Thomas, Steve }\end{array}$ \\
\hline Nelson, Bruce & Moore, Terrence \\
\hline Nelson, Robert & $\begin{array}{l}\text { Haley, Jerry } \\
\text { F.L.A. }\end{array}$ \\
\hline Nesmith, Willie James & Unknown $^{\mathrm{a}}$ \\
\hline Newton, Alan & Unknown $^{\mathrm{a}}$ \\
\hline O'Donnell, James & Unknown $^{\mathrm{a}}$ \\
\hline Ochoa, James & McCollum, James T. \\
\hline Odom, Kirk & Unnamed $^{\mathrm{c}}$ \\
\hline Ortiz, Victor & Unknown $^{\mathrm{a}}$ \\
\hline Pacyon, Douglas & Unknown $^{\mathrm{a}}$ \\
\hline Pallares, Jose & Unnamed $^{\mathrm{c}}$ \\
\hline Patterson, Maurice & Starkey, James \\
\hline Peacock, Freddie & Unknown $^{\mathrm{a}}$ \\
\hline Pendleton, Marlon & Unknown $^{\mathrm{a}}$ \\
\hline Peterson, Jamie Lee & Ryan, Jason Anthony \\
\hline Peterson, Larry & Unknown $^{\mathrm{a}}$ \\
\hline Phillips, Michael & Banks, Lee Marvin \\
\hline Phillips, Steven & Goodyear, Sidney Alvin \\
\hline Pierce, Jeffrey Todd & May Jr., Omar D. \\
\hline Pinchback, Johnny & Unknown $^{\mathrm{a}}$ \\
\hline Piszczek, Brian & Unknown $^{\mathrm{a}}$ \\
\hline
\end{tabular}




\begin{tabular}{|c|c|}
\hline Pope, David Shawn & Roberts, James Milton \\
\hline Powell, Anthony & Dixon, Jerry \\
\hline Rachell, Ricardo & Hawthorne, Andrew Wayne \\
\hline $\begin{array}{l}\text { Reynolds, Donald } \\
\text { Wardell, Billy }\end{array}$ & Unknown $^{\mathrm{a}}$ \\
\hline Richardson, Gerard & Unknown $^{\mathrm{a}}$ \\
\hline $\begin{array}{l}\text { Richardson, Harold } \\
\text { Saunders, Michael } \\
\text { Swift, Terrill } \\
\text { Thames, Vincent }\end{array}$ & Douglas, Johnny \\
\hline Richardson, James Joseph & Unknown $^{\mathrm{a}}$ \\
\hline Rivera, Juan & Unknown $^{\mathrm{a}}$ \\
\hline Roberts, Horace & $\begin{array}{l}\text { Leal, Joaquin } \\
\text { Harris Jr., Googie } \\
\text { Harris Sr., Googie }\end{array}$ \\
\hline Roberts, Rodney & Unknown $^{\mathrm{a}}$ \\
\hline Robinson, Anthony & Unknown $^{\mathrm{a}}$ \\
\hline Rodriguez, George & Unknown $^{\mathrm{a}}$ \\
\hline Rogers, Mandel & $\begin{array}{l}\text { Hines, Joseph } \\
\text { Jackson, Cedrick }\end{array}$ \\
\hline Rollins, Lafonso & Unknown $^{\mathrm{a}}$ \\
\hline Roman, Miguel & Mirando, Pedro \\
\hline Rose, Peter & Unknown ${ }^{\mathrm{a}}$ \\
\hline $\begin{array}{l}\text { Ruffin, Julius } \\
\text { Whitfield, Arthur Lee }\end{array}$ & Doxie, Aaron \\
\hline Saecker, Frederic & Unknown $^{\mathrm{a}}$ \\
\hline Salazar, Ben & Unknown $^{\mathrm{a}}$ \\
\hline Sarsfield, Eric & Unknown $^{\mathrm{a}}$ \\
\hline Scott, Calvin Lee & Sauls, Steven Wayne \\
\hline
\end{tabular}




\begin{tabular}{|c|c|}
\hline Scott, Winston & Unknown $^{\mathrm{a}}$ \\
\hline Scruggs, Dwayne D. & Unknown $^{\mathrm{a}}$ \\
\hline Shephard, David L. & Unknown $^{\mathrm{a}}$ \\
\hline Sledge, Joseph & Unknown $^{\mathrm{a}}$ \\
\hline Smith, Billy James & Unknown $^{\mathrm{a}}$ \\
\hline $\begin{array}{l}\text { Smith, Frank Lee } \\
\text { Townsend, Jerry }\end{array}$ & Mosley, Eddie \\
\hline Smith, Walter D. & Unknown $^{\mathrm{a}}$ \\
\hline Snyder, Walter & Unknown $^{\mathrm{a}}$ \\
\hline Sonnier, Ernest & $\begin{array}{l}\text { Breaux, Avery Gus } \\
\text { Thomas, Kirk Jerome }\end{array}$ \\
\hline Starks, Bennie & Unknown $^{\mathrm{a}}$ \\
\hline Sterling, Frank & Christie, Mark \\
\hline Stinson, Robert Lee & Price, Moses \\
\hline Sutherlin, David Brian & Unnamed $^{\mathrm{c}}$ \\
\hline Tall Bear, Johnny & Unknown $^{\mathrm{a}}$ \\
\hline Tapp, Christopher & Brian Dripps \\
\hline Taylor, Ronald Gene & Carroll, Roosevelt \\
\hline Thibodeaux, Damon & Unknown $^{\mathrm{a}}$ \\
\hline Thomas, Victor Larue & Unknown $^{\mathrm{a}}$ \\
\hline Thompson, Hubert & Unnamed $^{\mathrm{c}}$ \\
\hline Thurman, Philip Leon & Unnamed $^{\mathrm{c}}$ \\
\hline Tillman, James Calvin & Foster, Duane \\
\hline Toney, Steven & Unknown $^{\mathrm{a}}$ \\
\hline Towler, Raymond & Unknown $^{\mathrm{a}}$ \\
\hline Tribble, Santae & Unknown $^{\mathrm{a}}$ \\
\hline
\end{tabular}




\begin{tabular}{|c|c|}
\hline Turner, Keith & Unknown $^{\mathrm{a}}$ \\
\hline Vargas, Luis & Unknown $^{\mathrm{a}}$ \\
\hline Vasquez, David & Unknown $^{\mathrm{a}}$ \\
\hline Velasquez, Eduardo & Unknown $^{\mathrm{a}}$ \\
\hline Villasana, Armand & Unknown $^{\mathrm{a}}$ \\
\hline Waller, James & Unknown $^{\mathrm{a}}$ \\
\hline Waller, Patrick & $\begin{array}{l}\text { Bell, Byron } \\
\text { Simmons, Lemondo }\end{array}$ \\
\hline Wallis, Gregory & Unknown $^{\mathrm{a}}$ \\
\hline Warney, Douglas & Johnson, Eldred \\
\hline Washington, Calvin E. & Carrol, Bennie \\
\hline Washington, Earl & Tinsley, Kenneth Maurice \\
\hline Waters, Kenneth & Unknown $^{\mathrm{a}}$ \\
\hline Waters, Leo & Caulk, Joe Bill \\
\hline Watkins, Jerry & $\begin{array}{l}\text { McCormick, Joseph } \\
\text { Munson, Kenneth }\end{array}$ \\
\hline Watkins, John & Unknown $^{\mathrm{a}}$ \\
\hline Webb, III, Thomas & Harris, Gilbert Duane \\
\hline Webb, Mark & Unknown $^{\mathrm{a}}$ \\
\hline Webb, Troy & Unknown $^{\mathrm{a}}$ \\
\hline Webster, Bernard & Powell, Darren L. \\
\hline White, John Jerome & Perham, James \\
\hline Whitley, Drew & Unknown $^{\mathrm{a}}$ \\
\hline Wiggins, David Lee & Unknown $^{\mathrm{a}}$ \\
\hline Williams, Derrick Raphel & Unknown $^{\mathrm{a}}$ \\
\hline Williams, Jr., Johnny & Unknown $^{\mathrm{a}}$ \\
\hline
\end{tabular}




\begin{tabular}{|c|c|}
\hline Williams, Michael & Unknown $^{\mathrm{a}}$ \\
\hline Willis, Calvin & Unknown $^{\mathrm{a}}$ \\
\hline Willis, John & McGruder, Dennis \\
\hline $\begin{array}{l}\text { Wilson, Sharrif } \\
\text { Yarbough, Anthony }\end{array}$ & Unknown $^{\mathrm{a}}$ \\
\hline Woodall, Glen & Good, Donald Eugene \\
\hline Woodard, James Lee & Unknown $^{\mathrm{a}}$ \\
\hline Woods, Anthony & Unknown $^{\mathrm{a}}$ \\
\hline Woods, Cathy & Halbower, Rodney \\
\hline Wright, Anthony & Byrd, Ronnie \\
\hline Wyatt, Rickey Dale & Unknown $^{\mathrm{a}}$ \\
\hline Wyniemko, Kenneth & Gonser, Craig \\
\hline Yarris, Nicholas & Unknown $^{\mathrm{a}}$ \\
\hline York, Kenneth & Unknown $^{\mathrm{a}}$ \\
\hline Youngblood, Larry & Cruise, Walter \\
\hline
\end{tabular}

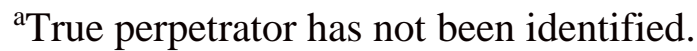

${ }^{b}$ Walter Ellis was the true perpetrator of two separate crime events, thus is listed twice.

${ }^{\mathrm{c}}$ True perpetrator was identified through DNA, but their name was not released to the public. 